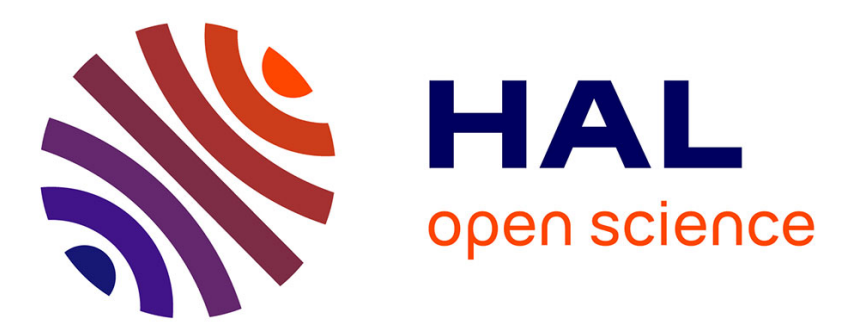

\title{
Late orogenic doming in the Eastern Betics: final exhumation of the Nevado-Filabride complex and its relation to basin genesis.
}

Romain Augier, Laurent Jolivet, Cécile Robin

\section{- To cite this version:}

Romain Augier, Laurent Jolivet, Cécile Robin. Late orogenic doming in the Eastern Betics: final exhumation of the Nevado-Filabride complex and its relation to basin genesis.. Tectonics, 2005, 24 (4), art $\mathrm{n}^{\circ} \mathrm{TC} 4003,19$ p. 10.1029/2004TC001687 . hal-00085026

\section{HAL Id: hal-00085026 https://hal.science/hal-00085026}

Submitted on 16 Apr 2012

HAL is a multi-disciplinary open access archive for the deposit and dissemination of scientific research documents, whether they are published or not. The documents may come from teaching and research institutions in France or abroad, or from public or private research centers.
L'archive ouverte pluridisciplinaire HAL, est destinée au dépôt et à la diffusion de documents scientifiques de niveau recherche, publiés ou non, émanant des établissements d'enseignement et de recherche français ou étrangers, des laboratoires publics ou privés. 


\title{
Late Orogenic doming in the eastern Betic Cordilleras: Final exhumation of the Nevado-Filabride complex and its relation to basin genesis
}

\author{
Romain Augier and Laurent Jolivet \\ Laboratoire de Tectonique, UMR 7072, Université de Pierre et Marie Curie, Paris, France
}

\section{Cécile Robin}

Geosciences, UMR 4661, Université de Rennes I, Rennes, France

Received 26 May 2004; revised 4 March 2005; accepted 28 March 2005; published 13 July 2005.

[1] The geometry, timing, and kinematics of late orogenic extension in the Betic Cordilleras pose the problem of a decoupling of upper crustal and lower crustal deformation regimes. Perpendicular directions of extension in metamorphic domes and nearby sedimentary basins remain unexplained. This paper puts kinematic constraints on the final exhumation of the Nevado-Filabride complex, focusing on the formation of metamorphic domes and their relations with the adjacent basins. Structural fabrics and kinematic indicators below the main shear zones as well as their relations with both published changing metamorphic P-T conditions and geochronological data were studied. Our approach describes (1) a consistent top-to-the-west shear parallel to dome axes of during D2 (i.e., during decompression) with distributed ductile flow and the onset of strain localization along major shear zones, (2) further strain localization along the major shear zones under greenschist facies conditions, during D3 leading to S$\mathrm{C}^{\prime}$ mylonites formation accompanied with a rock strong thickness reduction, (3) the divergence of shear direction on either limbs of domes during D3 showing the appearance of the dome geometry, and (4) a local evolution toward N-S brittle extension (D4) in the upper plate and formation of sedimentary basins. Continuous ductile to brittle top-to-the-west shear is compatible with the slab retreat hypothesis from the Miocene; the formation of domes which adds gravitational forces responsible for the final stages of exhumation is thus characterized by important kinematics changes necessary to explain coeval N-S opened basins. Later, from the upper Tortonian, a contractional event (D5) amplified the earlier domal structures forming the present north vergent folds. Citation: Augier, R., L. Jolivet, and C. Robin (2005), Late Orogenic doming in the eastern Betic Cordilleras: Final exhumation of the Nevado-Filabride complex and its relation to

Copyright 2005 by the American Geophysical Union. 0278-7407/05/2004TC001687 basin genesis, Tectonics, 24, TC4003, doi:10.1029/
2004TC001687.

\section{Introduction}

[2] Extensional structures such as large-scale detachments play a major role in exhuming metamorphic rocks in synorogenic [Platt, 1993; Jolivet et al., 1994; Lister and Raouzaios, 1996] or late orogenic contexts [Wernicke, 1981, 1992; Lister et al., 1984; Platt and Behrmann, 1986; Malavieille, 1993; Andersen, 1998]. The most characteristic detachments leading to metamorphic rocks exhumation are associated with the formation of sedimentary basins. The transition through time and space from ductile to brittle regime and a control of the geometry and infill of basins by the extensional detachment is often observed in late orogenic cases. Close association of metamorphic core complexes and extensional detachments have been described over all Mediterranean regions, in the Alps [Avigad et al., 1993; Henry et al., 1993; Agard et al., 2001], the Aegean [Gautier and Brun, 1994a, 1994b; Jolivet et al., 1998b; Gautier et al., 1999], the Tuscan archipelago and Tyrrhenian sea [Daniel and Jolivet, 1995; Jolivet et al., 1998a] or the Betic-Rif orogen [Crespo-Blanc et al., 1994a, 1994b; Vissers et al., 1995; Azañón et al., 1997; Martínez-Martínez et al., 2002, 2004; Augier, 2004]. The mechanism of formation of these structures and the causes of extension are still debated. Different models such as convective removal of lithospheric root, lithospheric delamination or slab roll-back followed by large-scale gravitational collapse could explain postorogenic extension [Malinverno and Ryan, 1986; Dewey, 1988; Platt and Vissers, 1989; Vissers et al., 1995; Seber et al., 1996; Lonergan and White, 1997]. In the case of the Aegean Sea, slab roll-back can be demonstrated with a clear migration of the volcanic arc with time from $30 \mathrm{Ma}$ onward [Le Pichon et al., 1995; Jolivet and Faccenna, 2000]. The case of the Betic-Rif orogen is more complex because the available space for roll-back was much narrower. Slab roll-back thus involved a complex kinematic evolution from frontal collision to back arc extension with large-scale block rotations and migration of both compressional and extensional fronts parallel to the orogen [Lonergan and White, 1997; Martinez-Martínez and Azañón, 1997]. It is thus crucial to decipher the respective 
roles of extension and compression in the formation of the present geometry. Previous studies [Galindo-Zaldivar et al., 1991; Jabaloy et al., 1993] have shown an apparent contradiction between a consistent E-W shear direction in the largest metamorphic dome (i.e., Sierra Nevada and Sierra de los Filabres) and the N-S to NNE-SSW direction of extension in the nearby basins, especially the HuercalOvera and Tabernas basins [Mora, 1993; Vissers et al., 1995; Pascual Molina, 1997; R. Augier et al., Post-orogenic extension of the eastern Betics and basin genesis: The example of the Huercal-Overa basin, submitted to International Journal of Earth Sciences, 2005, hereinafter referred to as Augier et al., submitted manuscript, 2005].

[3] In order to unravel the kinematics and better constrain the exhumation history of the Nevado-Filabride complex and its relation with the basin infill history, we have undertaken a structural study of both Nevado-Filabride and Alpujarride complexes as well as of the Neogene sedimentary basins deposited above the major shear zones. This paper presents mainly results from the core complexes while Augier et al. (submitted manuscript, 2005) describe the subsidence history versus the structural evolution of the Huercal-Overa basin and its possible relation with the Nevado-Filabride exhumation. To constrain the exhumation history, we used published P-T evolutions associated and radiometric ages (i.e., t).

\section{Geological Setting}

[4] In the convergent Mediterranean context, large-scale contractional and extensional structures coexist within arcuate orogenic belts such as the Hellenic arc, the Carpathians, the Calabrian arc and the Tell-Rif-Betic chain [Dewey, 1988; Vissers et al., 1995; Martínez-Martínez and Azañón, 1997]. All these orogenic segments display a convex orogenic front characterized by outward motion accommodated by shortening and thrusting and a concave side characterized by large-scale distributed extension [Malinverno and Ryan, 1986; Jolivet et al., 1998a; Jolivet and Patriat, 1999; Jolivet et al., 2003]. These systems evolve with their own internal dynamics not simply related to the overall convergence between Africa and Eurasia [Dewey et al., 1989; Jolivet et al., 2003; Faccena et al., 2003].

[5] The Betic cordilleras are classically divided into nonmetamorphic external zones and predominantly metamorphic internal zones [Egeler and Simon, 1969] limited by the internal-external boundary zone (i.e., IEBZ [Vissers et al., 1995], Figure 1). The external zones consist of the detached folded and thrusted sedimentary cover corresponding to the Iberian carbonated shelf (Prebetic) and slope/basinal environments (Subbetic). The external zones have been thrusted on the Hercynian Iberian platform (i.e., Iberian Meseta) toward the north and northwest creating the large Guadalquivir foreland basin filled by thick series of Neogene to recent sediments [Allerton et al., 1993; Sanz de Galdeano and Vera, 1992; GarciaCastellanos et al., 2002]. Internal zones, south of the external zones, can be geometrically described as "open domes and basins" with E-W trending domes and encased basins developed in between [Martínez-Martínez et al., 2004]. Domes consist of numerous stacked metamorphic thrust sheets divided and grouped into three main complexes, from bottom to top, the Malaguide, the Alpujarride and the Nevado-Filabride complexes, extensively covered by Neogene sedimentary basins. Stacking occurred during the pre-Miocene in a more easterly position, probably when the Alboran domain was a segment of the continuous alpine system [Bouillin et al., 1986; Royden, 1993; Lonergan and White, 1997; Jolivet et al., 2003; Platt et al., 2003; Spakman and Wortel, 2004].

[6] The Nevado-Filabride complex (i.e., hereafter noted NFC) is composed of three main metamorphic units [García-Dueñas et al., 1988a, 1988b; De Jong, 1991; Vissers et al., 1995] which are, from bottom to top: the Ragua (i.e., ex Veleta [Martínez-Martínez et al., 2002]), the Calar Alto and Bédar-Macael units corresponding to the Mulhacen complex [Garcia-Dueñas et al., 1988a]. The Mulhacen complex units consist of a broadly similar lithostratigraphic succession including Paleozoic black schists, light grey quartzites and metapelites traditionally assumed to be Permo-Triassic in age and Triassic metacarbonates whereas the Ragua unit is made of rocks only. A general agreement exists on the metamorphic evolution of the Mulhacen complex. Many authors recognize an early HP/LT metamorphism reaching eclogite facies followed by a strong recrystallization during a roughly isothermal decompression in the amphibolite or upper greenschist facies, depending on the unit, before final retrogression in the greenschist facies along a warm gradient (i.e., $\sim 60^{\circ} \mathrm{C} / \mathrm{km}$ [Gómez-Pugnaire and Fernández-Soler, 1987; Bakker et al., 1989; Jabaloy et al., 1993; Soto and Azañón, 1994; Augier et al., 2005]). As mentioned above, these rocks seem to have been exhumed, at least partly, by intense distributed extensional activity while contemporaneous shortening was affecting the external zones [Platt and Vissers, 1989; Frizon de Lamotte et al., 1991; Vissers et al., 1995; Lonergan and White, 1997; Martínez-Martínez and Azañón, 1997]. Exhumation of the complex was achieved by two distinctive suborthogonal extensional events affecting both Alpujarride and Nevado-Filabride complexes and often reactivating major thrusts [García-Dueñas et al., 1992; Crespo-Blanc et al., 1994b; Crespo-Blanc, 1995; González-Casado et al., 1995; Martínez-Martínez and Azañón, 1997]. The first one, Burdigalian-Langhian in age, is accommodated by the Contraviesa extensional fault system affecting the Alpujarride stack by a roughly N-S extension [Crespo-Blanc et al., 1994a, 1994b; Crespo-Blanc, 1995]. Timing of this first extensional event is well constrained with narrow radiometric age cluster from different isotopic systems [Zeck et al., 1989, 1992, 1998, 2000; Monié et al., 1994; Platt et al., 1996] consistent with both synextension and postextension sediment ages [Mayoral et al., 1994; Crespo-Blanc, 1995] whose timing and direction are consistent with the opening of the westernmost part of the Algerian basin domain [Martinez-Martínez et al., 2002]. Exhumation of both Alpujarride and Nevado-Filabride complexes were completed 


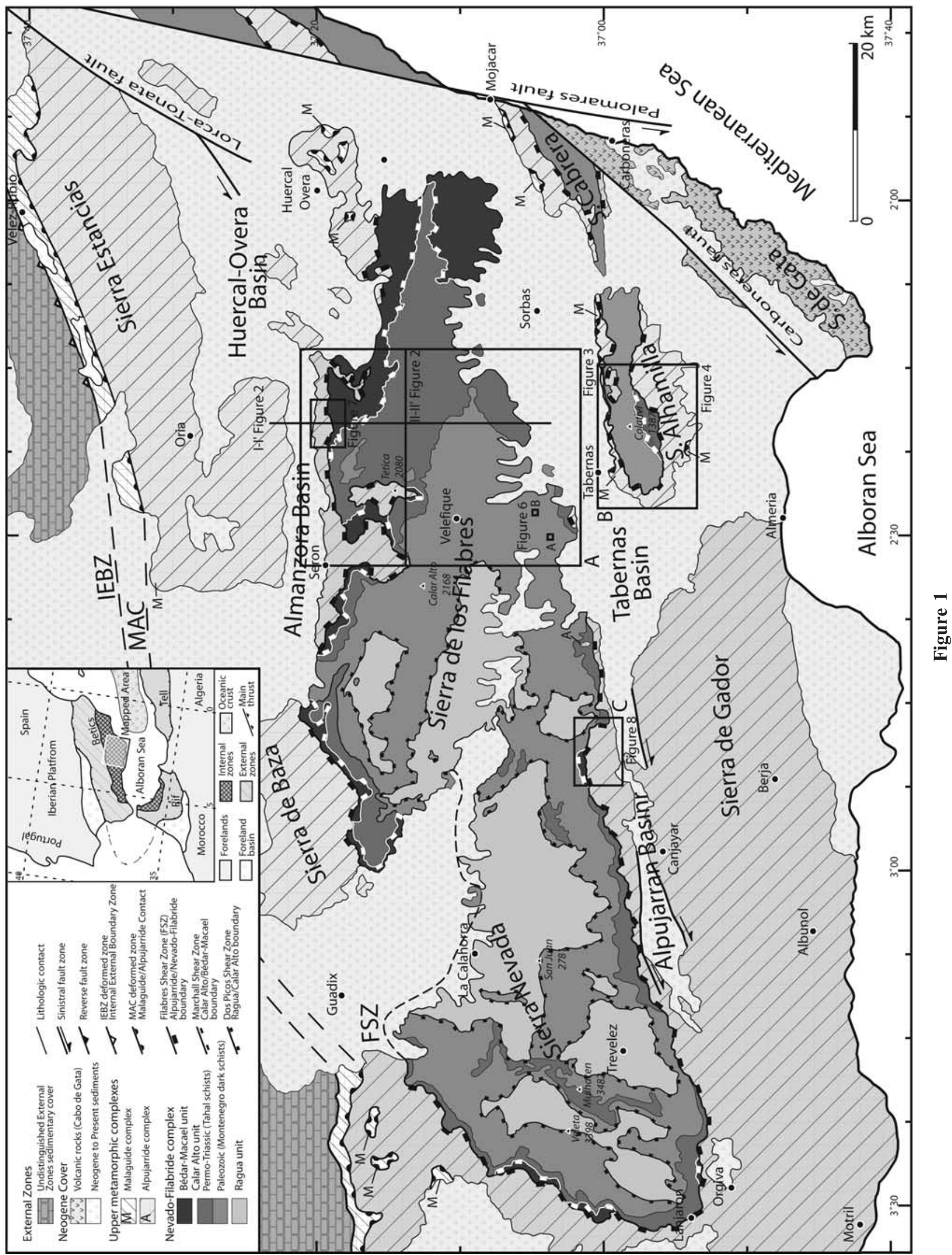


by a second set of low-angle shear zones mainly coinciding with Alpujarride/Nevado-Filabride boundary, the Filabres Shear Zone (i.e., FSZ [García-Dueñas et al., 1992; Martínez-Martínez et al., 2002]) and second-order, Intra Nevado-Filabride shear zones (i.e., Figures 1 and 2; Marchall and Dos Picos shear zones [García-Dueñas et al., 1992; González-Casado et al., 1995]). The footwall of these shear zones, strongly deformed, show a clear E-W to NE-SW stretching associated with a top-to-the-west sense of shear [Galindo-Zaldivar et al., 1989, 1991; GarciaDueñas et al., 1992; Jabaloy et al., 1993; GonzálezCasado et al., 1995; Martínez-Martínez et al., 2002, 2004].

[7] Contemporaneous Neogene sedimentary basins are particularly abundant, cropping out between metamorphic domes. Their stratigraphy is relatively similar [Sanz de Galdeano and Vera, 1992] and generally displays two infill events. The first one, Burdigalian-Langhien in age is badly preserved, then followed by unconformable upper Serravallian to recent thick deposits composing most of the infill (i.e., second infill event). Their evolution has been variously interpreted from compressional to purely extensional. Extensional models, which seems to better explain the Neogene evolution of the internal zones result from the observation of large-scale extensional features permitting alpine metamorphic rocks to exhume [Platt and Vissers, 1989; Jabaloy et al., 1993; Vissers et al., 1995; Martínez-Martínez et al., 2002]. In the HuercalOvera basin, most of the basin history is contemporaneous with normal faulting showing synrift infill at all scales as a consequence of consistent and continuous NNE-SSW extension [Mora, 1993; Vissers et al., 1995; Augier et al., submitted manuscript, 2005]. The major normal faults seem to listrically bend into the FSZ explaining the structural and sedimentary asymmetries of the basin, thus drawing an overall half graben [Vissers et al., 1995; Augier, 2004; Augier et al., submitted manuscript, 2005].

[8] However, extensional shear zones are not the most recent structures in the Betic cordilleras as a well documented, still active compressional event then reworked older structures from the upper Tortonian onward [Weijermars et al., 1985; Vissers et al., 1995]. The major structures produced by this late deformation are E-W large-scale open folds coeval with basins reversal [Weijermars et al., 1985; Ott d'Estevou and Montenat, 1990; Augier et al., submitted manuscript, 2005] and the activity of large-scale wrench fault zones [Weijermars, 1987; Reicherter and Reiss, 2001; Booth-Rea et al., 2003].

\section{Deformation History of the Nevado- Filabride Complex (NFC)}

[9] The NFC is characterized by a strong and regionally developed planar-linear fabric $\left(\mathrm{S}_{2} / \mathrm{L}_{2}\right)$ developed under the major part of the retrograde metamorphic evolution (i.e., roughly isotherm decompression; D2 event) associated with a discrete extensional crenulation cleavage (i.e., here noted $\mathrm{C}_{2}$ ) as already pointed out by Jabaloy et al. [1993]. Locally, the relations between the initial bedding $\left(\mathrm{S}_{0}\right)$ and the first schistosity $\left(S_{1}\right)$ in the hinges of $F_{1}$ folds (D1 event) are still observable but will not be studied in details in this paper. The overprinting of $\mathrm{S}_{0}$ and $\mathrm{S}_{1}$ by $\mathrm{S}_{2}$ is clearly visible within the hinges of $\mathrm{F}_{2}$ folds.

[10] This study focuses on the D2 deformation stage, mostly coinciding with the formation of the $\mathrm{S}_{2} / \mathrm{L}_{2}$ fabric and younger events (i.e., D3-D4), from the onset of extensional deformation to the final stages of exhumation under brittle conditions. At the end of the D2, in the most deformed levels, $\mathrm{S}_{2}$ is itself reworked by recumbent curved hinge folds $\left(\mathrm{F}_{3}\right)$ locally associated with a crenulation cleavage $\left(\mathrm{S}_{3}\right)$. Later, during final cooling, ductile deformation (D3 event, $\mathrm{C}_{4}$ extensional crenulation cleavage) and later brittle deformation (D4 event) completed the exhumation of the NFC.

\section{Early Ductile Deformation (D1-D2 Events)}

\subsection{Relics of Early Structures (D1)}

[11] The intensity of the $\mathrm{S}_{2} / \mathrm{L}_{2}$ fabric and the strong associated metamorphic overprint makes the identification and the study of earlier structures difficult (i.e., D1). These structures are nevertheless sparsely preserved in the core of the metamorphic units (i.e., far from the major shear zones, Figure 2).

[12] The relation between the initial bedding $\left(\mathrm{S}_{0}\right)$ and a first-phase schistosity $\left(\mathrm{S}_{1}\right)$ has already been pointed out by Langenberg [1972] and Vissers [1981]. $\mathrm{S}_{1}$, gently east or southeast dipping is axial planar to asymmetric folds $\left(\mathrm{F}_{1}\right.$ folds; Figure 2, stretch 2) which are often overturned toward the northwest as already proposed by Vissers [1981] and Jabaloy et al. [1992]. These structures are assumed to relate to the early stage of thickening under HP-LT metamorphic

Figure 1. Simplified geological map of the central and eastern Betic Cordilleras showing the main metamorphic units and tectonic contacts, modified after Vissers et al. [1995] and Martínez-Martínez et al. [2002]. Shown are the three "metamorphic complexes," from bottom to top, the Nevado-Filabride (reaching eclogite facies, i.e., Mulhacen complex), the Alpujarride (reaching blueschists to eclogite facies), and the Malaguide (anchizonal conditions). This study mainly focuses on the NFC in the areas illustrated by black boxes (i.e., A, B, C, namely, the eastern Sierra de los Filabres, the Sierra Alhamilla, and the Ohanes region respectively). The NFC is composed of three main metamorphic units which are, from bottom to top, the Ragua (i.e., ex Veleta, devoid of HP relics [Martínez-Martínez et al., 2002]), the Calar Alto, and Bédar-Macael units, the two latter corresponding to the Mulhacen complex and containing eclogitic relics [García-Dueñas et al., 1988a]. 


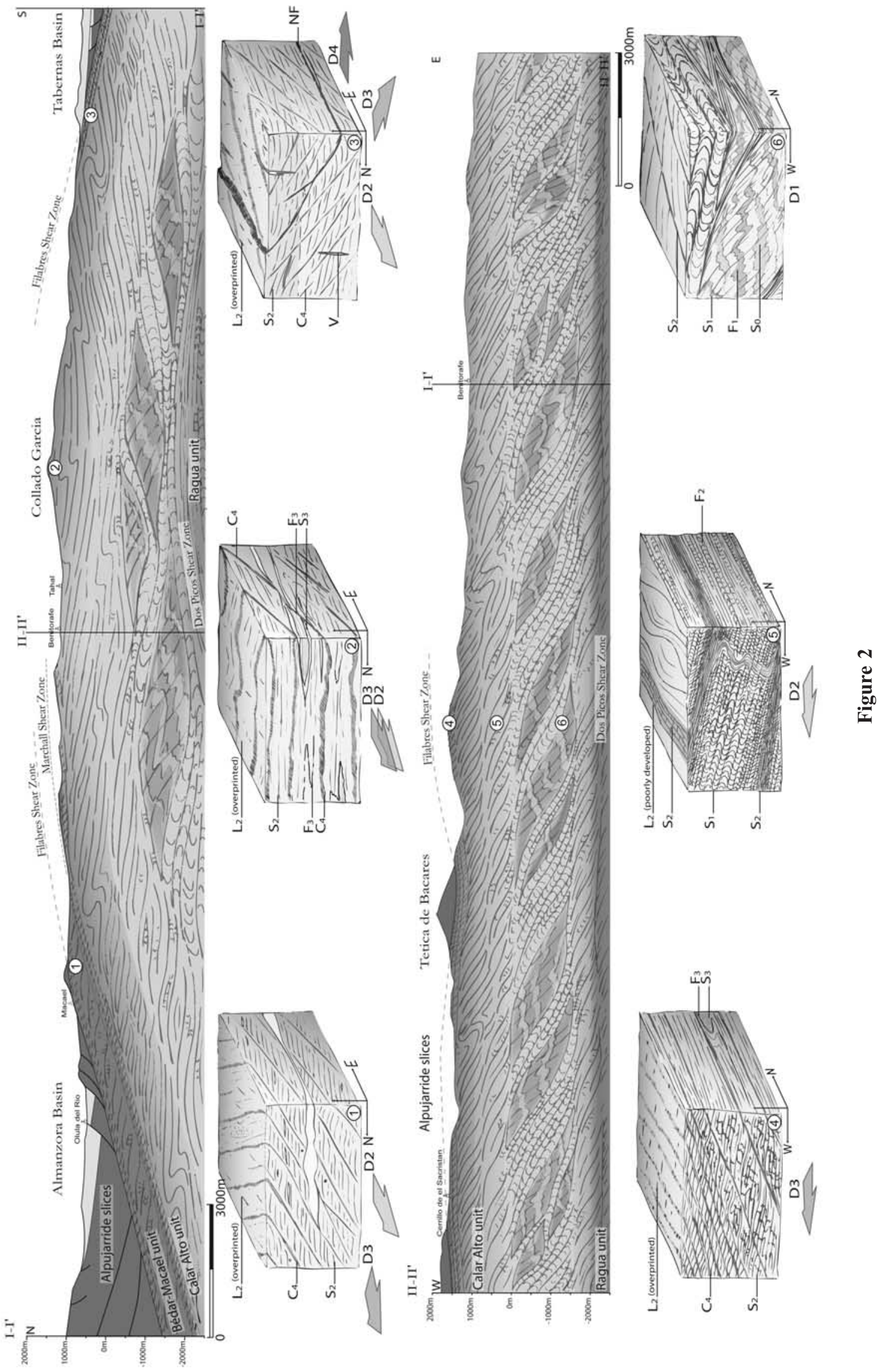


conditions [Vissers, 1981; Bakker et al., 1989] as it carries HP/LT mineral assemblages (i.e., Omph-Grt-Phg-Rt in the Bédar-Macael and Cld-Grt-Phg-Chl-Rt-Ky in the Calar Alto [Gómez-Pugnaire and Fernández-Soler, 1987; Bakker et al., 1989; Jabaloy et al., 1993; Soto and Azañón, 1994; Augier et al., 2005]). $\mathrm{S}_{1}$ is well developed in the pelitic layers, but not clearly developed within the intercalated quartzites and metaconglomerates showing instead a first set of quartz veins which trend roughly parallel to $S_{1}$. Thus these veins may form an important amount of the sheared veins observable in the whole complex. In the Sierra Alhamilla, the deformation associated with $\mathrm{S}_{2}$ and later structures are much more penetrative and $\mathrm{S}_{0}$ and $\mathrm{S}_{1}$ are seldom observed as already mentioned by Platt and Behrmann [1986].

\subsection{Development of $S_{2}$ and the LP/HT Event (D2)}

[13] In most of the NFC, the main structure is a penetrative, gently dipping, planar-linear fabric $\left(\mathrm{S}_{2} / \mathrm{L}_{2}\right)$ developed during D2. Relics of the HP paragenesis strongly deformed by $S_{2}$ are preserved in the core of the complex where $S_{2}$ is a differentiated crenulated cleavage axial-planar to curved hinge $\mathrm{F}_{2}$ folds (mainly parallel to $\mathrm{L}_{2}$ ). In this domain, the deformation is dominated by roughly coaxial flow with a strong flattening component and presents neither lineation nor shear bands (Figure 2, stretch 5).

[14] In more deformed domains, $S_{2}$ foliation carries a strong and penetrative E-W stretching lineation $\left(\mathrm{L}_{2}\right)$ which is more intense toward the main shear zones, the FSZ which roofs the complex and the Intra Nevado-Filabride shear zones (i.e., Marchall and Dos Picos shear zones [GonzálezCasado et al., 1995]). Lineation trajectories (i.e., flow lines) are roughly parallel and E-W trending, showing little smaller-scale variations (Figure 3a). Similar results were already presented by Jabaloy et al. [1993] based on the same kinematic indicators and quartz $\langle\mathrm{C}\rangle$ axis fabric data. At the vicinity of the shear zones, kinematic indicators such as shear bands $\left(\mathrm{S}-\mathrm{C}^{\prime}\right)$, relatively distributed, here noted $\mathrm{C}_{2}$, rotated objects, porphyroblasts and their pressure shadows or asymmetric folds indicate a consistent noncoaxial flow indicating a well regulated top-to-the-west sense of shear. In the Calar Alto unit, which represents most of the studied area, the synkinematic paragenesis (i.e., Grt-Phg-Bt-Chl $\pm \mathrm{St} \pm \mathrm{Ky}$ [Soto and Azañón, 1994; Augier et al., 2005]) is characteristic of upper greenschist facies conditions at the scale of the unit.
In the core of the Calar Alto unit, in domains where $\mathrm{S}_{2}$ escaped from further greenschists retrogression, thermobarometric data indicate conditions of $510^{\circ} \mathrm{C} \pm 50^{\circ} \mathrm{C}$ for $4,3 \pm 2 \mathrm{kbar}$ [Jabaloy et al., 1993]. This result illustrates the late reequilibration of $\mathrm{S}_{2}$ paragenesis which seems to have been stable over a large pressure range at roughly the same temperature as already proposed by [Gómez-Pugnaire and Fernández-Soler, 1987; Jabaloy et al., 1993; Soto and Azañón, 1994]. The increasing intensity of the $\mathrm{S}_{2} / \mathrm{L}_{2}$ fabric toward the top of the complex indicates the possible activity of the (proto?-) FSZ. The tectonic activity along this shear zone could be responsible for the rapid isothermal decompression of the footwall rocks during D2 [England and Richardson, 1977; England and Thompson, 1984; Ring et $a l ., 1999]$. Increasing deformation is also observable toward the Intra Nevado-Filabride shear zones (i.e., Marchall and Dos Picos shear zones) with roughly similar kinematics as pointed out by González-Casado et al. [1995].

\section{3. $\mathrm{S}_{3}$ Crenulation Cleavage (Late D2 Stage)}

[15] Curved hinge folds $\mathrm{F}_{3}$ (occasionally recumbent) affecting $\mathrm{S}_{2}$ are located in the highest positions of the complex. An axial plane crenulation cleavage of variable intensity developed locally $\left(\mathrm{S}_{3}\right)$. The trends of these folds are variable but mostly parallel to the $\mathrm{L}_{2}$ stretching lineation reflecting an important constrictional component superposed on E-W stretching as proposed by Soto et al. [1990] and Soto [1991]. The $\mathrm{L}_{2}$ lineation is locally folded when fold hinges are oblique to the stretching direction. These folds correspond to the Fp folds described by Jabaloy et al. [1993] and the $\mathrm{F}_{3}$ folds of De Jong [1991] and De Jong and Bakker [1991], who both distinguished two different sets with axis trending $\mathrm{N} 60^{\circ}-70^{\circ} \mathrm{E}$ and $\mathrm{N} 110^{\circ}-$ $130^{\circ} \mathrm{E}$. We interpret these folds in terms of progressive deformation as a result of the continuation of both E-W stretching and constrictional regime already responsible of the $S_{2} / L_{2}$ fabric formation. Thus formation of these $F_{3}$ folds makes part of the D2 event (i.e., late D2).

\section{Late Ductile Deformation History of the Nevado-Filabride Complex (D3 Event)}

[16] All previous structures are affected by a late extensional cleavage $\left(\mathrm{C}_{4}\right)$. This cleavage locally highly penetra-

Figure 2. Interpretative cross sections of the Sierra de los Filabres (i.e., N-S and E-W; for location, see Figure 1) showing the geometrical relations between successive foliations and associated structures. The most penetrative structure is the planar-linear fabric $\mathrm{S}_{2} / \mathrm{L}_{2}$ with increasing intensity toward the top of the complex (i.e., toward the FSZ) and Intra NevadoFilabride shear zones (i.e., Marchall and Dos Picos shear zones [González-Casado et al., 1995]). Synthetic interpretative 3-D sketches (noted 1 to 6) inspired from field observations illustrate with more details the relations of structure succession. Shown are the successive deformation events labeled (D1 to D4) and associated microstructures. The three upper 3-D sketches (sketches 1 to 3) rather illustrate the lateral variation of the late deformation (D3) on top of the complex on a N-S cross section, note the divergent patterns of the $\mathrm{C}_{4}$ in respect of the $\mathrm{L}_{2}$ invariably trending E-W. Late brittle deformation (D4) is sometime observable (i.e., southern Sierra de los Filabres) where tectonic transport direction is consistently N-S (sketch 3). The three lower 3-D sketches (sketches 4 to 6) rather illustrate the vertical distribution of the deformation on a E-W cross section from the core to the shallower parts of the complex. Note the continuous strain localization from D2 to D4 along major shear zones (i.e., the FSZ and the Marchall and the Dos Picos shear zones) and conversely the preservation of D1 and early D2 relics in the less deformed domains. 


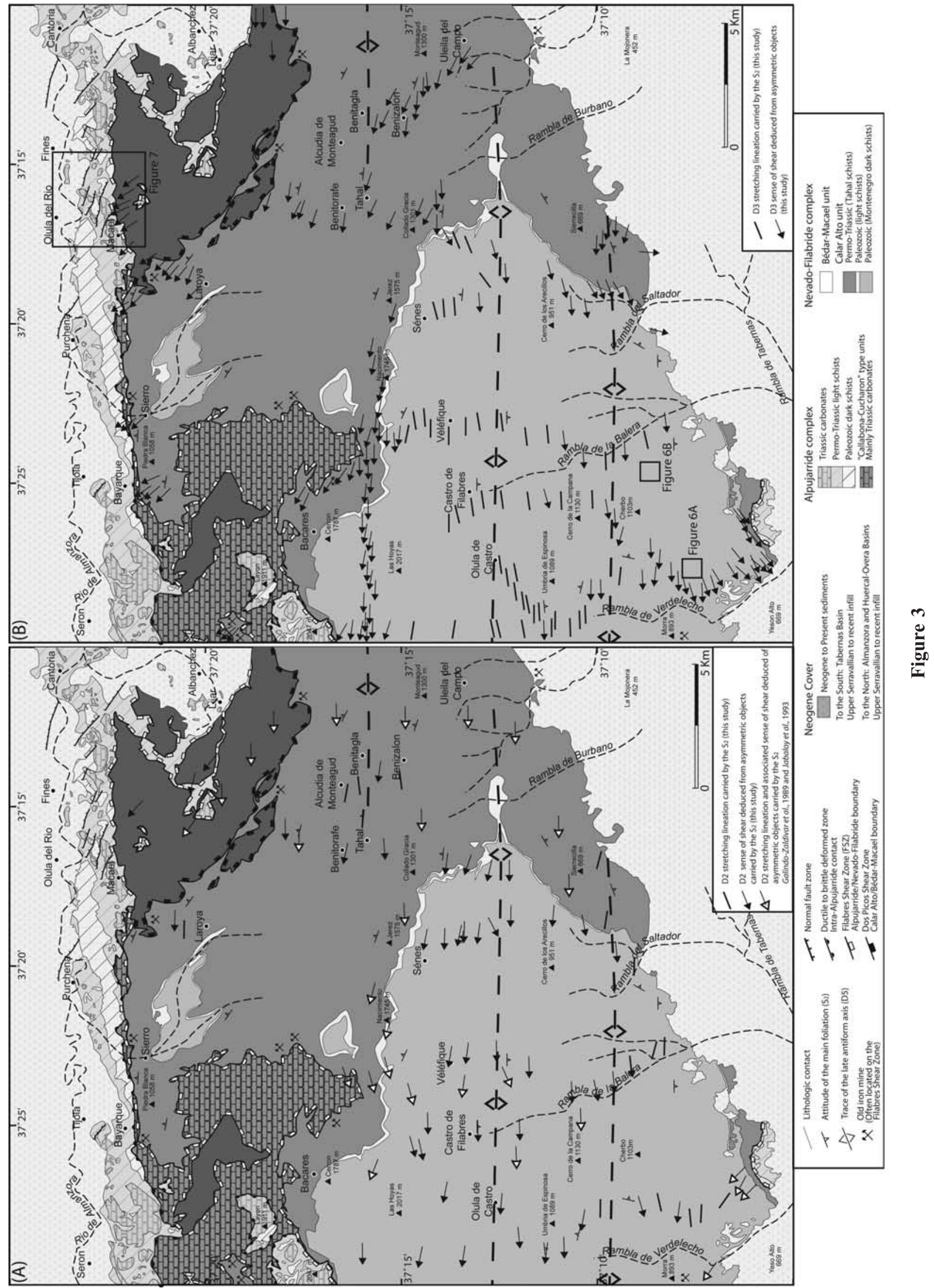


tive, is restricted to the vicinity of major shear zones, in particular along the FSZ.

\subsection{Late Extensional Crenulation Cleavage}

[17] Late extensional crenulation cleavage $\left(\mathrm{C}_{4}\right)$ is mainly observed in the Permo-Triassic light schists as well as in the uppermost part of the Paleozoic black schists where overlying lithostratigraphic units are tectonically thinned (e.g., Figure 2, east of Tetica de Bacares). These late extensional shear bands show clear differences to the $S_{2}$ and $S_{3}$ fabrics:

[18] $* \mathrm{C}_{4}$ clearly offsets $\mathrm{S}_{2}, \mathrm{~S}_{3}$ (i.e., when developed) and all earlier structures (i.e., when preserved; Figure 2, stretch 2). When $S_{3}$ is not present the distinction between $C_{2}$ and $\mathrm{C}_{4}$ is made according to the greater angle between $\mathrm{C}_{4}$ and $\mathrm{S}_{2}$ than between $\mathrm{C}_{2}$ and $\mathrm{S}_{2} . \mathrm{C}_{4}$ are thus much more localised indicating further strain localization with cooling.

[19] $* \mathrm{C}_{4}$ is associated with the crystallization of large amounts of elongated chlorite which clearly postdates the $\mathrm{S}_{2} / \mathrm{L}_{2}$ paragenesis. Thermobarometric estimates (G. BoothRea et al., Tectonometamorphic evolution of metapelites in the Nevado-Filabride complex, southern Spain: Insights from multiequilibrium thermobarometry, submitted to Terra Nova, 2005, hereinafter referred to as Booth-Rea et al., submitted manuscript, 2005) on phengite-chlorite couples [Vidal and Parra, 2000; Trotet et al., 2001a, 2001b; Parra et al., 2002] located within $\mathrm{C}_{4}$ extensional shear bands computed with TWEEQU 2.02 software [Berman, 1991] reveal lower grade conditions than for $\mathrm{S}_{2} / \mathrm{C}_{2}$ samples. $\mathrm{C}_{4}$ is coeval with the last part of the P-T path with cooling from $530^{\circ} \mathrm{C}$ and $4-3 \mathrm{kbar}$ to $300-350^{\circ} \mathrm{C}$ and $2-1 \mathrm{kbar}$ [GómezPugnaire and Fernández-Soler, 1987; Bakker et al., 1989; Jabaloy et al., 1993; Booth-Rea et al., submitted manuscript, 2005].

[20] $\mathrm{C}_{4}$ extensional cleavage affects a thinner zone than $\mathrm{S}_{2}$ (and $\mathrm{S}_{3}$ ), indicating a progressive localization of deformation along major shear zones, in particular the FSZ (Figure 2, stretch 4). Thus the degree of noncoaxiality and the finite strain increase mostly toward the top of the complex. In the uppermost part of the footwall, late shear bands form a single set of structures and their dip angles show large variations between $15^{\circ}$ to $40^{\circ}$. Higher values $\left(60^{\circ}\right.$ to overturned structures) are sometimes found and are interpreted to be caused by the rotation of older structures. This domain and especially the immediate vicinity of the FSZ, has accumulated a great part of the NFC cooling history with a progressive increase of the shear component and a strong overprint of older structures. The NevadoFilabride rocks of the Sierra Alhamilla are all strongly deformed and provide along their southern border one of the most spectacular mylonitic deformation of the studied domain already described by Platt and Behrmann [1986].

[21] Below this domain, the deformation is less noncoaxial with the appearance of antithetic shear bands. This conjugate set, however, remains less abundant than the first one with dips varying from $10^{\circ}$ to $45^{\circ}$. Locally, in the deepest part of the affected zone, both sets are equally represented, suggesting a rather coaxial flow component. Below, the $\mathrm{S}_{2} / \mathrm{L}_{2}$ fabric are fossilized together with its associated paragenesis without significant rotations allowing the mapping presented on Figures $3 \mathrm{a}$ and 4.

\subsection{Large-Scale Structures Associated With the Late Extensional Crenulation Cleavage}

[22] As a preliminary conclusion, the NFC shows form D2 to D3 a succession of deformation phases which we interpret as a single continuous extensional event with strain localization during exhumation (i.e., here cooling) and the transition from a ductile to a brittle regime along major shear zones. $S_{1}$ is found only in the core of the complex within isolated lenses preserved from further deformation. An upward increase of shear is observed toward the main contact with the Alpujarride complex (i.e., FSZ) as well as the Intra-Nevado-Filabride shear zones showing a continuous top-to-the-west shear sense during both D2 and D3. In addition, we observed during D3 a progressive change in shear direction and a progressive outward orientation of the sense of shear toward the limbs of the Sierras (Figures $3 \mathrm{~b}$ and 4). The best example of this pattern at the scale of a Sierra is displayed in the Sierra Alhamilla (Figures 4 and 5).

[23] The Sierra Alhamilla range forms a large-scale E-W trending open fold which acquired its present geometry during the late Tortonian (i.e., D5 [Platt et al., 1983; Weijermars et al., 1985; Martínez-Martínez et al., 2002, 2004]). Here, the NFC is divided into two tectonic units. The lower one, which constitutes the main part of the Sierra, corresponds to Paleozoic dark schists and quartzites of the Calar Alto unit whereas the upper one, cropping out only in the south, corresponds to the Bédar-Macael unit [MartinezMartinez and Azañón, 1997]. Study of the D3 deformation reveals a top-to-the-west sense of shear along the dome axis accompanied by progressive rotation toward the north on the northern limb and toward the south on the southern limb (Figures 4 and 5). This pattern was already recorded, but not explained in the structural work of Platt and Behrmann [1986] on the southern limb of the Sierra Alhamilla using quartz $\langle\mathrm{C}\rangle$ axis analysis. Figure 5 displays orientation of the

Figure 3. D2 and D3 deformation structures in the central Sierra de los Filabres, after a compilation of Instituto Geológico y Minero de España (IGME) [1978, 1977, 1973a, 1973b]. (a) Stretching lineation $\mathrm{L}_{2}$ and associated sense of shear (C2) developed during D2 (i.e., under amphibolite and upper greenschist facies; black arrows are our data and white arrows represent a compilation from Galindo-Zaldivar et al. [1989] and Jabaloy et al. [1993] original studies). (b) Late stretching lineation and associated sense of shear (C4) developed during D3 (i.e., under greenschist facies). Note the transition between well-regulated E-W stretching associated with a top-to-the-west sense of shear during D2 and the curved pattern of the late lineations (D3) characterizing the last ductile deformation. Later, under brittle conditions (D4), the situation evolved under to N-S extension which caused the subsidence of the neighboring sedimentary basins. Also note the location of old iron mines which are often symptomatic for the FSZ [Leine, 1966; Westra, 1970; Torres-Ruiz, 1983]. 


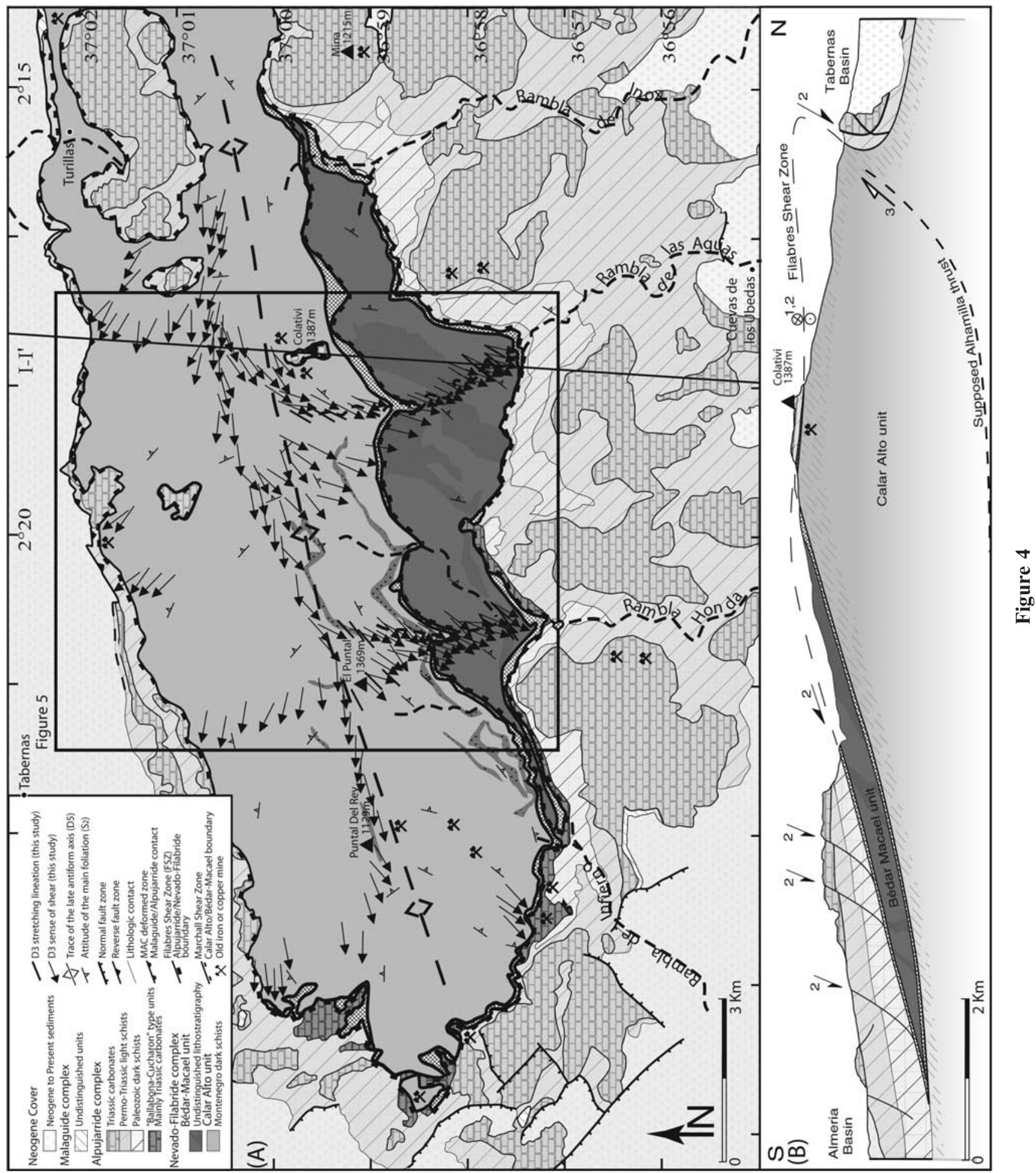




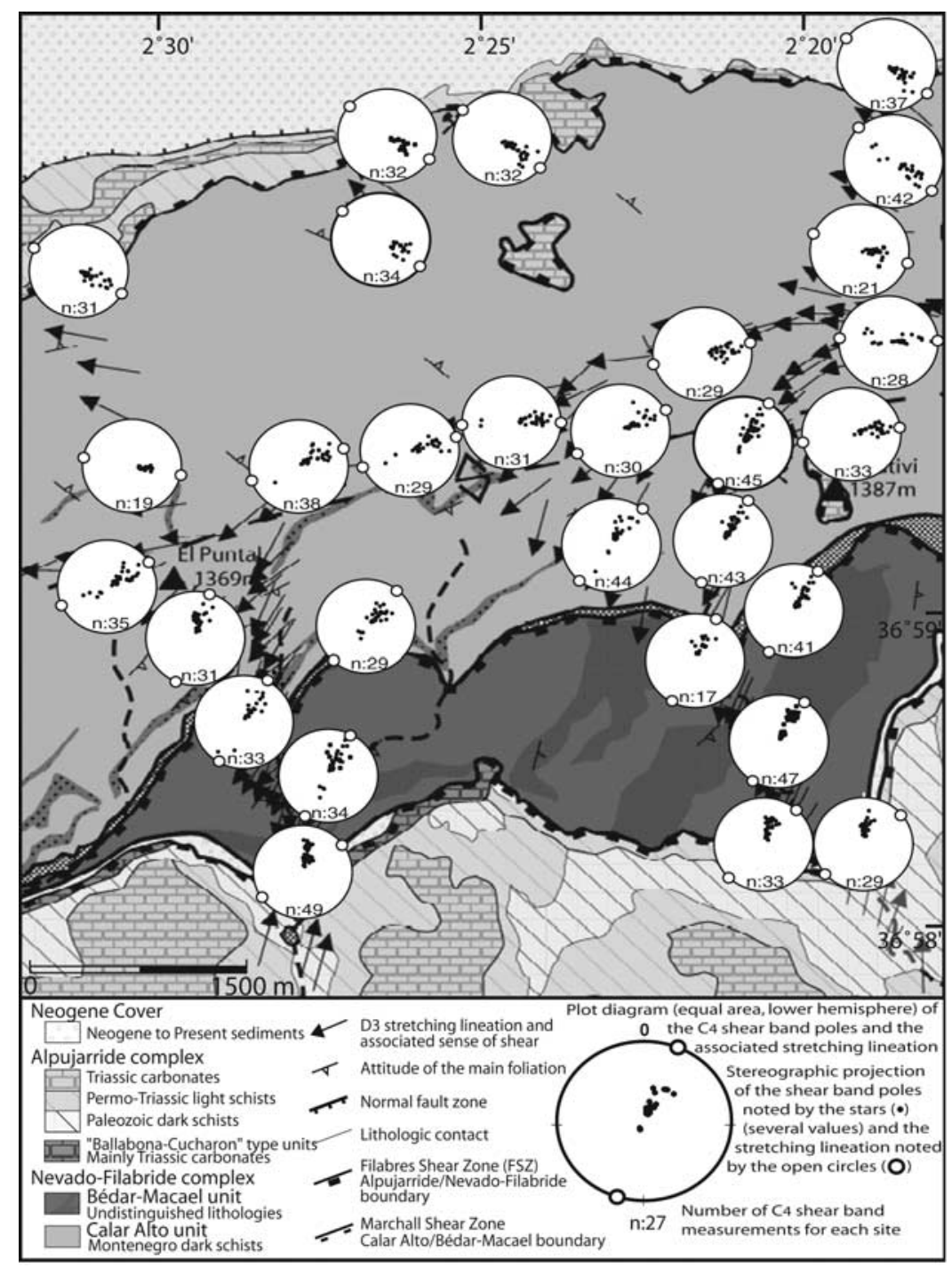

Figure 5. Close-up view of the central part of the western Sierra Alhamilla (location on Figure 4). Open circles are D3 lineations and black stars are the poles of the associated shear bands $\left(\mathrm{C}_{4}\right)$ both restored with respect to the present-day dip of the foliation. $\mathrm{C}_{4}$ poles are parallel to the lineation in most of the Sierra indicating the reliability of this criterion as kinematic indicator except at the vicinity of the FSZ, south of the Sierra where there are locally characterized by an obliquity reaching $30^{\circ}$.

lineations and associated shear band poles $\left(\mathrm{C}_{4}\right)$ and in the western of the Sierra Alhamilla. These data show the progressive northward and southward rotation of both lineations and shear bands. In the southernmost outcrops of the Sierra Alhamilla the lineation is locally oblique to the transport direction deduced from the $\mathrm{C}_{4}$ extensional shear bands (i.e., ECC). Platt and Behrmann [1986] used this obliquity to discard extensional crenulation cleavage as shear sense indicators in the Sierra Alhamilla and preferred quartz $\langle C\rangle$ axis fabrics. Our study shows that this obliquity is only local and that in most of the Sierra, the sense of shear can be deduced from the attitude of $\mathrm{C}_{4}$. In respect with the intense D3 deformation, most of the $\mathrm{S}_{2} / \mathrm{L}_{2}$ fabric has been overprinted (not represented on Figure 4). $\mathrm{L}_{2}$, seldom

Figure 4. D3 deformation structures on a simplified geological map of the western Sierra Alhamilla modified after Platt et al. [1983] and Platt and Behrmann [1986]. (a) Late stretching lineation and associated sense of shear (C4) developed during D3. The curved pattern of the D3 lineations is even more obvious than in the Sierra de los Filabres. This distinctive pattern between consistent E-W stretching during D2 and the diverging extensional directions during D3 leads us to propose that the acquisition of domal geometry occurred between D2 and D3. (b) Simplified geological N-S cross section of the Sierra Alhamilla: 1, E-W stretching and top-to-the-west sense of shear (event D2); 2, divergent extension, top-to-theNW to north and top-to-the-SSW to the south (event D3); and 3, approximately N-S compression with formation of the anticlinorium on a thrust (event D5, from the upper Tortonian). 


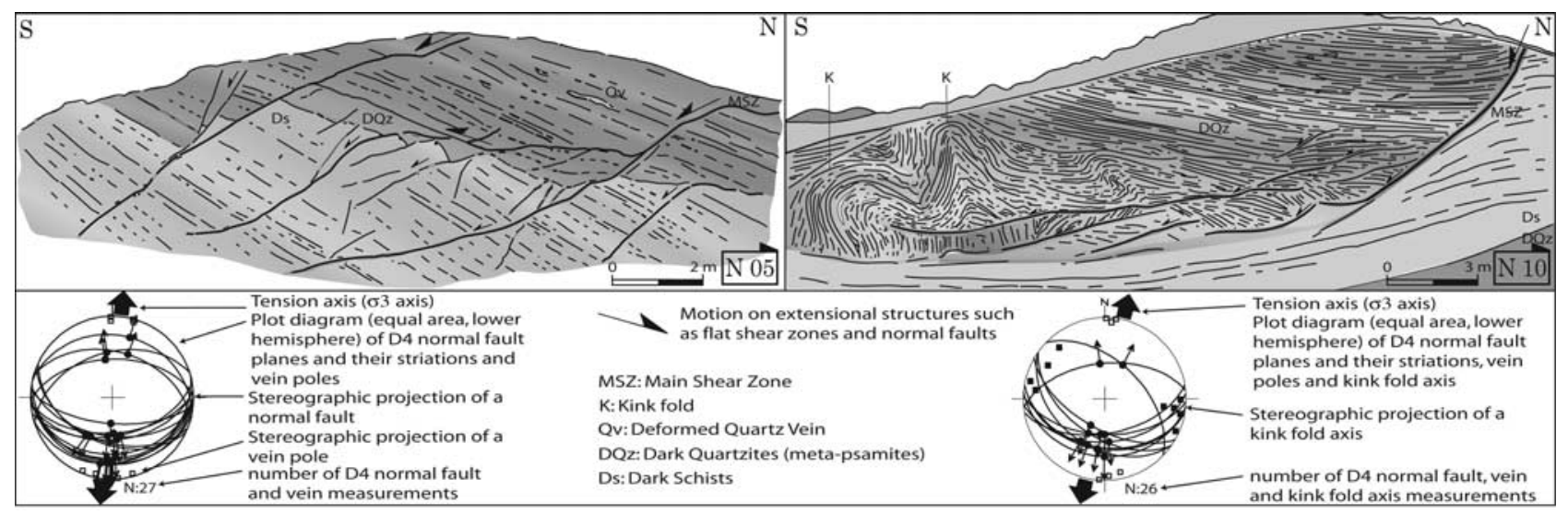

Figure 6. Relation between D4 listric faults and kink folds north of Gergal (Figure 1). Note that the main shear zone is characterized by thick fault gauge. Plot diagrams of the main faults of the outcrop (mainly done with faults out of the sketch) are interpreted in terms of stress axes (i.e., tension axis, $\sigma 3$ [Angelier, 1984, 1991]). For the two sites at a distance of $4 \mathrm{~km}$, fault slip analysis reveals a roughly N-S extension with a clear dominating south directed tectonic transport.

preserved in lower strain domains, reveal a consistent E-W stretching.

[24] Divergent pattern of both lineation and $\mathrm{C}_{4}$ shear bands is also observable at the scale of the central Sierra de los Filabres (Figure 3b). Such divergence is particularly obvious in the northern limb of the Sierra in the Macael region where later brittle deformation (i.e., D4) has not reworked ductile features (Figure 7).

\subsection{Timing of the Late Deformation Events}

[25] Monié et al. [1991] and De Jong [1991, 1993] and more recent studies by De Jong et al. [2001] and De Jong [2003] show phengite cooling ages around 18-16 Ma here interpreted as the age of the crossing of the $400 \pm 50^{\circ} \mathrm{C}$ isotherm [Hames and Bowring, 1994; Kirschner et al., 1996; Villa, 1998; Agard et al., 2001] that coincide approximately with the brittle-ductile transition. These ages would thus correspond to the beginning of cataclastic deformation along the major detachment surfaces as proposed by Monié et al. [1991]. While the end of the NFC exhumation is precisely dated, its beginning is much more subject to controversy due to its wide age spectrum ranging from lower Eocene to middle Miocene [Monié et al., 1991; López Sánchez-Vizcaino et al., 2001; De Jong, 2003]. The recent publication of $15 \mathrm{Ma} \mathrm{U}-\mathrm{Pb}$ ages on zircons from Sierra Nevada pyroxenites supposed to have formed close to the high-pressure peak by López Sánchez-Vizcaino et al. [2001] and thus interpreted by De Jong [2003] to indicate the age of the end of the HP event makes the interpretation even more problematic.

\section{Brittle Deformation and Neogene Basins (D4 Event)}

[26] The last increments of extensional deformation are accommodated by D4 ductile-brittle and later by brittle structures, low- to high-angle normal faults.

\subsection{Filabre Shear Zone (FSZ)}

[27] The FSZ is also the major deformation structure in the brittle regime cropping out along $250 \mathrm{~km}$ around the metamorphic domes. The FSZ geometry shows ramps cutting down section toward the west and flats where it is parallel to $\mathrm{S}_{2}$ (i.e., décollement [Martínez-Martínez et al., 2002]).

[28] Displacement of the hanging wall under brittle conditions is attested by a thick $(5-150 \mathrm{~m})$ zone of cataclasites, fault rocks, mylonitic gypsum and carbonate matrix breccias mainly derived of the underlying mylonite and ultramylonite zone (i.e., D3 zone). We noted the presence of an intercalated unit between the Alpujarride and NevadoFilabride rocks which is an equivalent of the BallabonaCucharon unit [Kampshuur et al., 1972] initially described in the Sierra de Almagro [Simon, 1963]. It has been widely prospected and exploited because of its intense mineralization with iron ore and other material like barite, gypsum and copper sulphurs (i.e., mine symbols Figures 3, 4, and 5 [Leine, 1966; Westra, 1970; Torres-Ruiz, 1983]).

\subsection{Smaller-Scale Brittle Structures}

[29] D4 normal faults and veins are widespread. Their abundance however increases toward the FSZ. In the following, we describe brittle structures in both footwall and hanging wall of the FSZ. Field evidences of footwall brittle deformation are provided in the example of the southern Sierra de los Filabres (i.e., Gergal region, Figure 6). Examples of hanging wall are located on the both sides of the Sierra de los Filabres near Macael (Figure 7) in the north and near Ohanes in the south (Figure 8).

\subsubsection{Footwall Deformation: Southern Limb} of the Sierra de los Filabres

[30] The southern central Sierra de los Filabres consists of Paleozoic monotonous dark schists belonging to the Calar Alto unit (Figure 6). This formation is tectonically covered through the FSZ by minor Alpujarride klippes 
overlaid by late Neogene to recent sedimentary deposits. This area is characterized by a penetrative ductile-brittle to brittle deformation postdating both the E-W $\mathrm{S}_{2} / \mathrm{L}_{2}$ fabric and the later top-to-the-SW $\mathrm{C}_{4}$ shear bands (i.e., post-D2 and D3, Figure 2, stretch 3).

[31] The most characteristic structures of this region are low-angle normal faults (Figure 6) reactivating earlier minor ductile shear zones which listrically bend down into the $\mathrm{S}_{2}$ foliation forming listric faults with large rotations of their hanging wall. Tectonic transport on these structures is consistently southward with only a few antithetic normal faults (Figure 6). The footwall unit is also often deformed by kink folds mainly due to the accommodation of the motion along the flat where faults terminate (i.e., Figure 6). As shown in Figure 6 , the tension axis $(\sigma 3)$ deduced from paleostress analysis of these structures is clearly trending $\mathrm{N}-\mathrm{S}$ associated with a dominant south directed tectonic transport (Figure 2, stretch 3; D4).

6.2.2. Hanging Wall Deformation: Examples of Macael and Ohanes Regions

[32] The Macael region (Figure 7) displays one of the clearest evidences of brittle extensional deformation of the Alpujarride rocks linked to the motion along the FSZ as already proposed further west (i.e., Seron region, Figure 1 [Orozco et al., 1999]).

[33] The footwall is composed of Bédar-Macael PermoTriassic light schists showing a penetrative D3 ductile deformation (i.e., NW-SE to NNW-SSE lineation and associated top-to-the-NW to $\mathrm{NNW} \mathrm{C}_{4}$ shear bands) which totally overprints earlier structures.

[34] Alpujarride rocks (i.e., most Permo-Triassic and Triassic) are separated from the underlying NevadoFilabride rocks by the shallow dipping (e.g., 15-20 $0^{\circ}$ ) FSZ. The whole Alpujarride unit is transected by listric normal faults offsetting and displacing the Alpujarride Triassic carbonate rocks by several tens to hundreds of meters (Figure 7b). These faults, explaining the tilting of the hanging wall bedding and schistosity, root in the FSZ. The hanging wall half graben of each structure is filled by red continental breccias assumed to be Serravallian or Tortonian in age [Briend, 1981; Briend et al., 1990; Montenat and Ott d'Estevou, 1990; Mora, 1993; Augier et al., submitted manuscript, 2005]. The FSZ and the associated listric faults thus seem to control the geometry and the tectonic subsidence of the Almanzora basin with a N-S to NNE-SSW brittle extension (e.g., tension axis, Figure 7c).

[35] The Ohanes region also displays clear evidence of brittle extensional deformation of the Alpujarride rocks linked to D4 motions along the FSZ (Figure 8). The footwall is mainly composed of the uppermost part of the Bédar-Macael unit which is affected by typical greenschist $\mathrm{C}_{4}$ shear bands indicating a top-to-the-SW-to-SSW shear sense. The Alpujarride rocks are separated from the underlying Nevado-Filabride rocks by the (shallow dipping) FSZ mostly characterized by a several tens of meters thick cataclastic zone of mylonitic gypsum, carbonated breccias of various lithologies and locally iron ores on which root the main normal faults affecting the Alpujarride rocks. The hanging wall syncline of the southernmost normal fault is filled with presumed Serravallian red conglomerates [Montenat and Ott d'Estevou, 1990; Pascual Molina, 1997; Poisson et al., 1999] similar to those previously described. Normal faults thus seem to control the geometry and the tectonic subsidence of the Alpujarran basin with a $\mathrm{N}-\mathrm{S}$ brittle extension (Figure $8 \mathrm{~b}$ ).

\subsection{Extensional Basin Genesis}

[36] Geometry and kinematics of the FSZ (e.g., Figures 7 and 8) responsible for most of the NFC exhumation under brittle conditions (i.e., during D4) are consistent with structural and paleostress analysis of the main faults of the Huercal-Overa and Tabernas basins (i.e., N-S to NNESSW tension axis [Mora, 1993; Vissers et al., 1995; Pascual Molina, 1997; Augier et al., submitted manuscript, 2005]). This also explains the marked asymmetry of the structure and the infill of the basins, half graben shaped, resulting from the geometry of the FSZ and major normal faults dipping away from the dome.

[37] In addition, cooling ages data from Johnson et al. [1997] on zircons (closure temperature (CT) $\sim 250^{\circ} \mathrm{C}$ [Tagami and Shimada, 1996]) and on apatites (CT $\sim 60-$ $110^{\circ} \mathrm{C}$ [Hurford, 1990; Gunnell, 2000]) indicate that final stages of exhumation occurred in the studied segment of the Sierra de los Filabres from $11.9( \pm 0.9)$ to $8.9( \pm 2.9) \mathrm{Ma}$. Thus this result shows that last increments of extensional deformation along the FSZ are the coeval with the deposition of disorganized red breccias at the base of the sedimentary infill of neighboring basins (i.e., HuercalOvera and Tabernas basins [Mora, 1993; Vissers et al., 1995; Pascual Molina, 1997]) containing the first NevadoFilabride detritus [Ruegg, 1964; Kleverlaan, 1989; Briend et al., 1990; Poisson et al., 1999; Augier et al., submitted manuscript, 2005].

[38] Tectonic subsidence of the basins as well as their infill is thus closely linked with the exhumation of the NFC. D4 brittle deformation is then sealed by upper Tortonian sediments (e.g., southern slope of the Sierra de los Filabres, Figure 1 [Kleverlaan, 1989; Pascual Molina, 1997; Poisson et al., 1999]) indicating the end of extensional motions along the FSZ.

\section{Discussion and Conclusions}

\subsection{Strain Localization Within the Nevado-Filabride Complex}

[39] A first-phase schistosity $\left(\mathrm{S}_{1}\right)$, assumed to relate to the stacking event [Vissers, 1981; Bakker et al., 1989] is preserved only in low-strain domain in the core of the complex where seldom relics of initial bedding $\left(\mathrm{S}_{0}\right)$ are also preserved. The planar linear $\mathrm{S}_{2} / \mathrm{L}_{2}$ fabric formed during D2 which coincide decompression from eclogite to amphibolite and upper greenschist facies. $\mathrm{S}_{2}$ affects a considerable thickness of rocks reaching locally more than $2000 \mathrm{~m}$ [Jabaloy et al., 1993] strongly overprinting older fabrics and mineral associations. In most of this domain, $\mathrm{S}_{2}$ is associated with $\mathrm{L}_{2}$-parallel fold hinges $\left(\mathrm{F}_{2}\right)$ indicating a constrictional component as pointed out by Soto et al. 


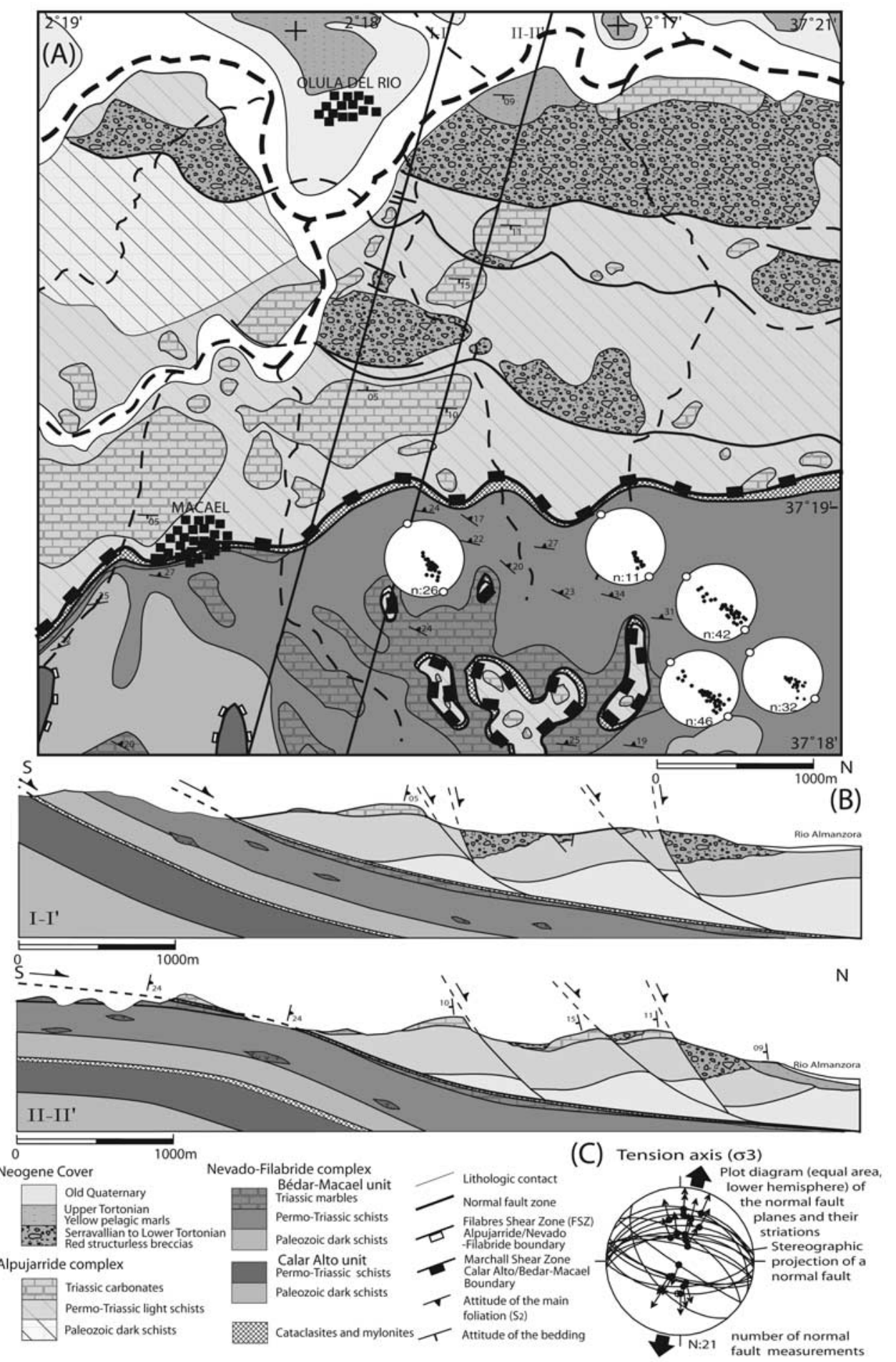

Figure 7. (a) Simplified geological map of the Macael region after IGME [1973] and our own data (location Figure 1). (b) Simplified geological cross sections parallel to the direction of D4 (i.e., brittle extension, here NNE-SSW). (c) Stereographic projection of the main fault zones interpreted in terms of stress axes (tension axis, $\sigma_{3}$ [Angelier, 1984, 1991]). Brittle extension is NNE-SSW with a clear dominating NNE directed tectonic transport. D3 lineations and associated $\mathrm{C}_{4}$ shear bands (i.e., formalism is given in Figure 5) are parallel indicating an NNW-SSE stretching associated with a top-to-the-NNW sense of shear. 

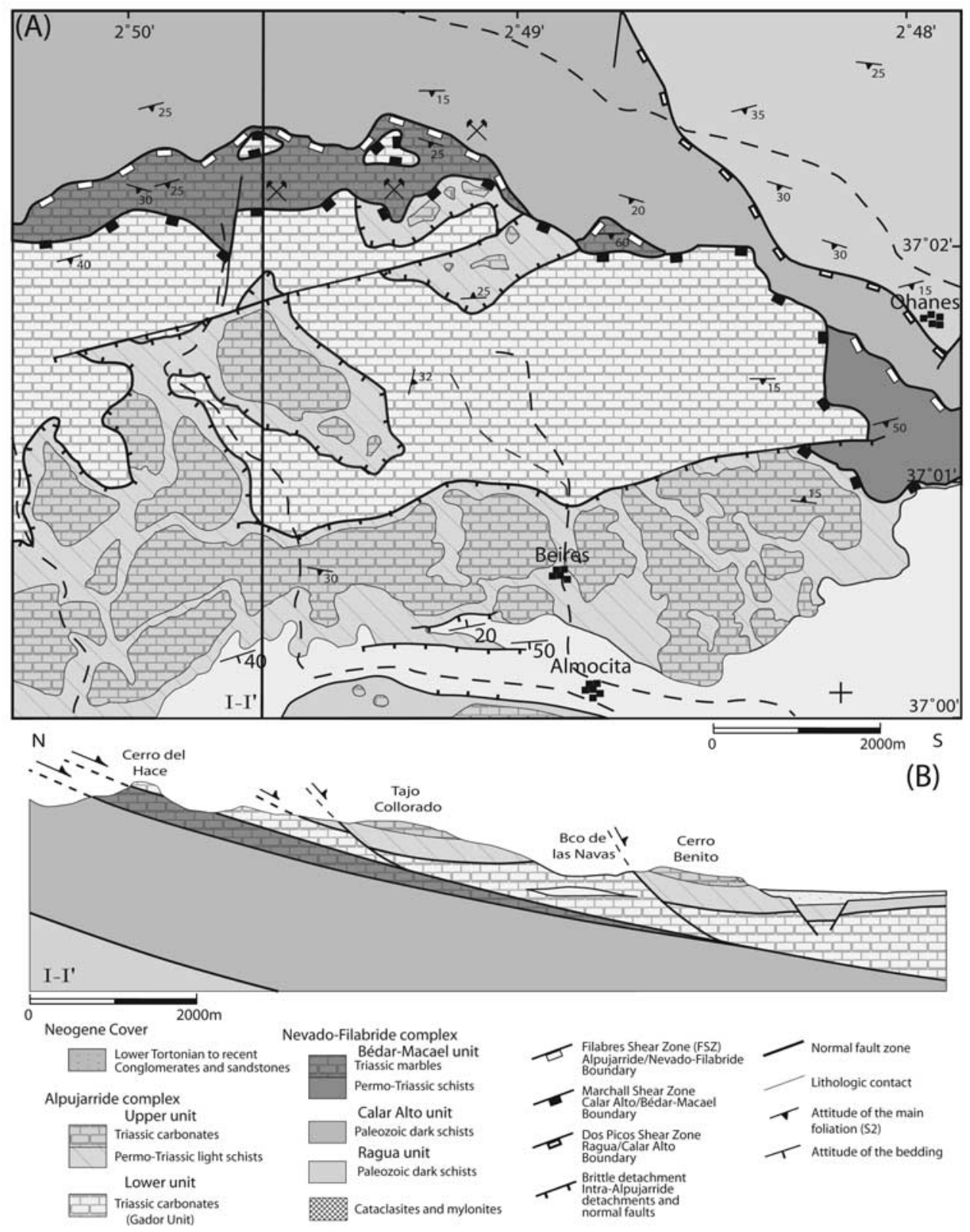

Figure 8. (a) Simplified geological map of the Ohanes region after IGME [1977] and our own data (for location, see Figure 1). (b) Simplified geological cross sections parallel to the local direction of D4 (i.e., $\mathrm{N}-\mathrm{S})$. The dominating tectonic transport is south.

[1990] and Soto [1991]. Kinematic indicators as well as the $\mathrm{L}_{2}$ are absent or rare in the core of the $\mathrm{NFC}$ illustrating a roughly coaxial deformation whereas they tend to be less ambiguous and more frequent toward the major shear zones, in particular the FSZ, accompanied by the progressive disappearance of $S_{0}$ and $S_{1}$ features. This indicates an upward increase of strain accompanied by a transition from coaxial flow in the core of the complex to noncoaxial flow toward the top and the first evidence of strain localization along the FSZ. Younger ductile extensional structures, formed during cooling and final retrogression into greenschist facies conditions (D3) indicate further strain localization with a strong reduction of the rock thickness affected by both the $\mathrm{F}_{3}$ folds (and the associated $\mathrm{S}_{3}$ foliation) and the $\mathrm{C}_{4}$ shear bands. Strain localization of less importance also occurred along IntraNevado-Filabride shear zones during D3 as already pointed out by González-Casado et al. [1995] thus accompanied by the formation of similar low-grade mylonites (i.e., $\mathrm{C}_{4}$-type shear bands). Below, $\mathrm{S}_{2} / \mathrm{L}_{2}$ fabrics and associated paragenesis are thus fossilized without any significant later retrogression or deformation in low-strain domains. Exhumation of the NFC is completed by motions on the FSZ under brittle conditions accompanied by formation of 
thick cataclasites mostly derived from the underlying D3 mylonites.

[40] To summarize, the NFC is characterized by a progressive strain localization from the core, where structures predating $\mathrm{S}_{2}$ are preserved toward the top of the complex where a part of the deformation is progressively concentrated along the FSZ. This spatial evolution from the core of the NFC toward the FSZ has thus to be considered as a time section along which both prograde (i.e., however difficult to reconstruct) and the whole retrograde metamorphic and structural evolutions of the NFC are recorded, partitioned and preserved as a function of strain localization. This evolution will now be considered as a guideline for studying the deformation evolution, not in vertical as already presented but rather on the horizontal plan.

\subsection{Dome Formation and "Local" Implications}

[41] In an attempt to describe the formation of metamorphic domes and the associated of surrounding basins, we propose the following model (Figure 9). After a consistent top-to-the-west shear during D2 stage (i.e., Figure 9b) prevailing during, at least, a part of the decompression, final exhumation stages were in turn, characterized by important kinematics changes. Yet, during D3, both stretching lineation and $\mathrm{C}_{4}$ shear bands indicate divergent extension directions (i.e., D3 stage, Figure 9c). As seen above, we interpret such appearance of a divergent pattern as the first evidence for the formation and the onset of dome uplift at shallow depth (Figure 9c). Acquisition of domal geometry implies creation of forces controlled by the newly formed dome "slopes" which are added to the overall EW crustal stretching. The situation then evolved under brittle conditions with an amplification of this pattern while the rocks completed their exhumation, leading to local predominance of N-S extension (i.e., D4 stage, Figure 9c). Cooling ages [Johnson et al., 1997] illustrate that the core of the Sierra de los Filabres dome were exhumed earlier than their adjacent limbs as already mentioned by MartínezMartínez et al. [2002, 2004], in addition of a progressive younging of the fission tracks ages toward the west [Johnson et al., 1997]. This result is also confirmed by older structural studies reporting down-slope motions of Alpujarride klippes along the FSZ [e.g., Langenberg, 1972; Orozco et al., 1999] whose close link with hanging wall normal faults controls the deposition of upper Serravallian conglomerates forming the base of the basins infill (e.g., Huercal-Overa and Tabernas basins). The geometry of the FSZ, dipping away from the dome also explains the marked asymmetry of the basins, half graben shaped.

[42] The divergent pattern (D3) of both greenschist lineations and associated shear bands makes a gradual transition from the E-W ductile stretching (D2) to late local N-S brittle extension (D4). Extension is, however mostly controlled by E-W crustal stretching coupled with rising gravitational collapse induced by the uplifting of domes. Brittle extension is thus not only related to overall crust stretching but rather by dome frameworks. Proposed model reconciles the paradox of E-W ductile deformation and the subradial brittle extension responsible, in the eastern Betics for the forma- tion of the Neogene basins at right angle from the ductile extension.

\subsection{Discussion on the Mechanism of Dome Formation}

[43] Evolution of the E-W trending large-scale open folds, which characterize the first-scale structure and topography of the eastern internal Betics, have been a point of debate for a long time. These folds have first been interpreted so far from only resulting from the late Tortonian contractional event [Platt et al., 1983; Weijermars et al., 1985; Montenat and Ott d'Estevou, 1990; Sanz de Galdeano and Vera, 1992], lateral ramps on west directed thrusts [Frizon de Lamotte et al., 1995] to isostasic structures due the progressive unroofing of the footwall unit by major detachments [Galindo-Zaldivar et al., 1989, 1991; Martínez-Martínez et al., 2002, 2004] as often proposed in core complex settings [Wernicke, 1992; Axen et al., 1995; Avigad et al., 1997].

[44] First evidence of the uplift of domes is indicated by appearance of $\mathrm{D} 3$ diverging extensional direction shear bands postdating D2 E-W stretching $\left(\mathrm{S}_{2} / \mathrm{L}_{2}\right)$. Last mineral reequilibrations of the $\mathrm{S}_{2} / \mathrm{L}_{2}$ fabric occurred at P-T conditions of the order of $550-500^{\circ} \mathrm{C}$ for 3-4 kbar [GómezPugnaire and Fernández-Soler, 1987; Bakker et al., 1989; De Jong, 1991; Jabaloy et al., 1993; Soto and Azañón, 1994; Augier et al., 2005]. Domal geometry is thus acquired at a depth of the order of $10 \mathrm{~km}$ (i.e., assuming a 2.85 density crust). Nevertheless, one of the last models of dome formation [Martínez-Martínez et al., 2002] puts forward EW folding behind the extensional front progressively migrating westward the isostatically readjusted segments. This model, suggesting a contractional origin of the domes (i.e., folds) well explains the large-scale structures but does not account either for the kinematic changes, under brittle conditions necessary to explain the contemporaneous formation basins nor for the early formation of the dome, already visible in the greenschist facies.

[45] In addition, significant constrictional component is often visible on the field at different scales, with the example of the $F_{2}$ and $F_{3}$ folds. The formation of domes parallel to the direction of stretching has already been explained elsewhere as the result of constrictional extension bounded by perpendicular compression [Hartz et al., 1994; Lammener and Weger, 1998]. In turn, domal geometry has been strongly amplified by the contractional event that occurred during the upper Tortonian [Weijermars et al., 1985; Ott d'Estevou and Montenat, 1990; Vissers et al., 1995; Martínez-Martínez et al., 2002, 2004]. It is attested, for example, by the formation of the Sierra Alhamilla anticlinorium which is thrust onto folded and overturned upper Tortonian sediments [Weijermars et al., 1985; Kleverlaan, 1989]. This contractional event was responsible for the uplift of the entire Alboran domain disconnecting the now emerged basins from the Alboran Sea [Comas et al., 1992, 1999] lifting Messinian and Pliocene marine marls up to $1000 \mathrm{~m}$ [Martínez-Martínez et al., 2002, 2004], and for the formation of the present-day Sierras [Braga et al., 2003] as well as for the activity of large-scale strike-slip faults such as the Palomares and the Carboneras 


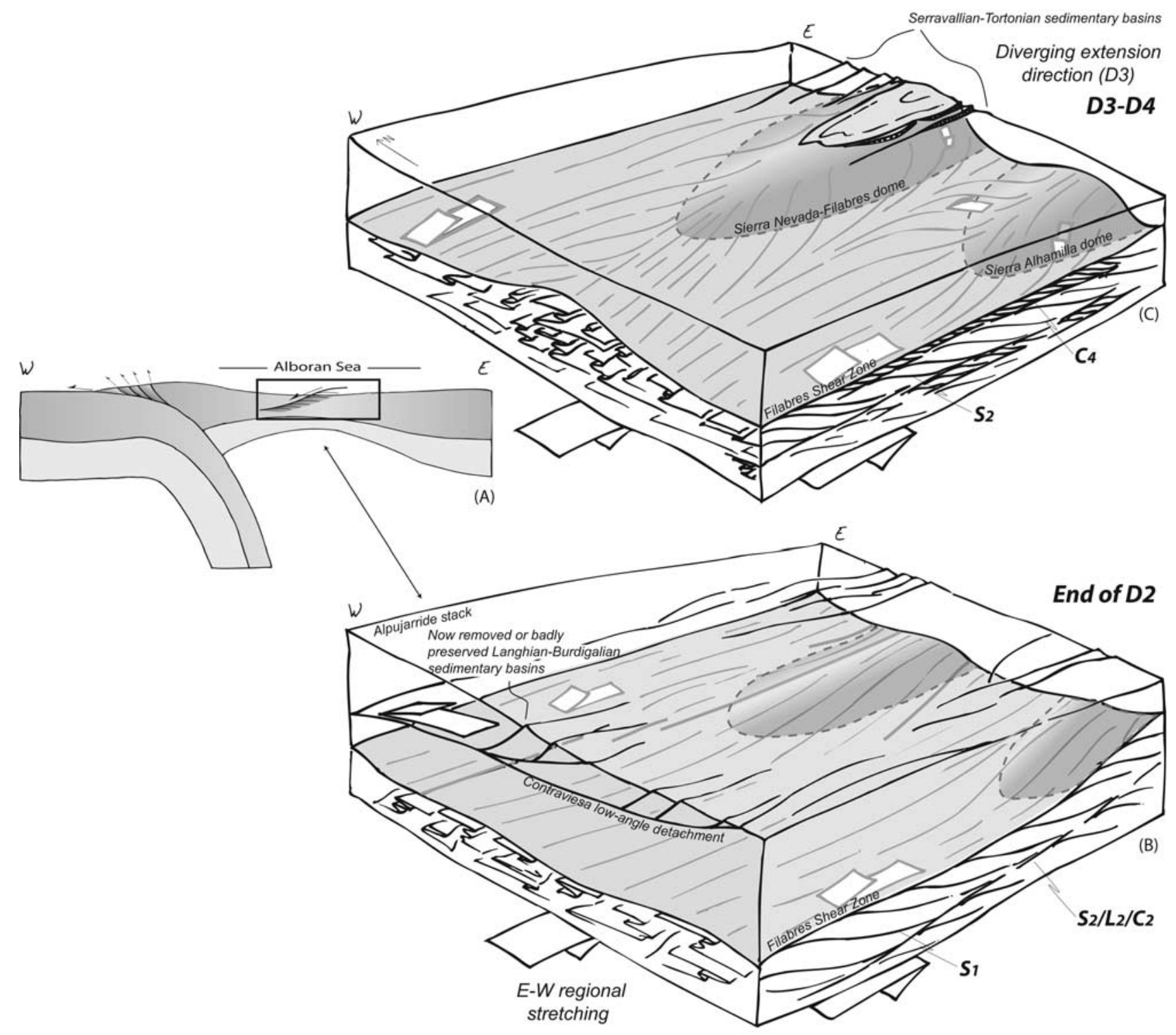

Figure 9. (a) Schematic W-E cross section of the northern Alboran Sea. The box encompasses the region shown in Figures $9 \mathrm{~b}$ and $9 \mathrm{c}$. Three-dimensional sketches showing the evolution of the NFC exhumation in two stages: (b) during the end of D2, deformation in mainly accommodated by the FSZ characterized by a regional top-to-the-west sense of shear. This deformation produced in the footwall block (i.e., the NFC) the $\mathrm{S}_{2} / \mathrm{L}_{2}$ fabric. Note the well regulated E-W trend of the $\mathrm{L}_{2}$ lineation. (c) During D3 (i.e., cooling under greenschist conditions), domal framework is progressively acquired with superimposition on the overall E-W extension of a lateral extension component (i.e., down-slope, roughly N-S motion). Listric D4 normal faults root on the reactivated FSZ and control the subsidence of basins such as the Huercal-Overa and the Tabernas basins.

left-lateral faults [Weijermars, 1991] (Figure 1). Present-day domes are thus to be considered as, at least for a part, formed from the upper Tortonian onward as a result of the still active compressional event (D5) as already suggested by MartinezMartinez et al. [2002]. In addition, the high topography of the Sierra Nevada (i.e., Mulhacén peak, $3482 \mathrm{~m}$ ) seems to be partly linked and developed in response to intracrustal flow [Martínez-Martínez et al., 2004].

\subsection{Larger-Scale Implications}

[46] Convergence between Africa and Eurasia [Dewey et al., 1989; De Mets et al., 1990; Mazzoli and Helman, 1994] does not explain the arcuate shape of the Rif-Betic orogenic system. Early models involved an Alboran microplate moving westward [Andrieux et al., 1971; Leblanc and Olivier, 1984; Sanz de Galdeano, 1990] which collided as a rigid block both with Africa and Iberia margins. This 
hypothesis was then abandoned with the discovery of large-scale distributed extension of the Alboran domain [Platt and Vissers, 1989; Garcia-Dueñas et al., 1992; Jabaloy et al., 1993; Crespo-Blanc, 1995; Comas et al., 1999; Martinez-Martinez et al., 2002]. This led to alternative models involving either delamination of lithospheric mantle [Platt et al., 1998], extensional collapse caused by convective removal of a previously thickened lithospheric root [Platt and Vissers, 1989; Vissers et al., 1995] or back arc extension behind a westward retreating subduction [Royden, 1993; Lonergan and White, 1997; Platt et al., 2003], responsible of the strong thinning of the Alboran "plate" [Comas et al., 1999]. More recently, an east dipping oceanic slab has been imaged by tomography beneath the Alboran Sea [Gutscher et al., 2002; Spakman and Wortel, 2004].

[47] Our study shows consistent E-W crustal stretching during the most part of the exhumation of the NFC from the lower crust then completed by brittle deformation (i.e., Figure 9b). First evidences of the E-W stretching appeared during the formation of $\mathrm{S}_{2} / \mathrm{L}_{2}$ fabric (D2). Attempts of dating peak thermal conditions associated with the last mineral reequilibrations on $\mathrm{S}_{2}$ indicate ages of $20 \mathrm{Ma}$
[Monié et al., 1991] coeval with peak temperature conditions affecting the Alpujarride complex [Zeck et al., 1992, 1998; Monié et al., 1994; Platt et al., 1998; Platt and Whitehouse, 1999].

[48] Platt et al. [2003] have demonstrated that at the same time, the Alboran domain was at least located $250 \mathrm{~km}$ eastward of its present position with respect to Iberia forming the termination of the alpine collisional orogen [Rosenbaum et al., 2002; Jolivet et al., 2003]. The Alboran orogen started its migration toward the west, internally affected by distributed E-W extensional collapse phase [García-Dueñas et al., 1992; Jabaloy et al., 1993; Martínez-Martínez et al., 2002]. Our data and domeforming processes thus both favor the slab retreat model for the evolution of the Alboran domain in the Betics-Rif; the FSZ being one of the major extensional structure accommodating back arc extension (Figure 9a).

[49] Acknowledgments. This work was supported by the CEPAGE and the contribution of the UMR 7072 (CNRS). We gratefully acknowledge J. P. Platt for a very nice and instructive field trip in March 2003. Blanka Sperner, John Platt, and anonymous reviewer are thanked for their constructive reviews of the first drafts of this paper.

\section{References}

Agard, P., L. Jolivet, and B. Goffé (2001), Tectonometamorphic evolution of the Schistes lustrés complex: Implications for the exhumation of HP and UHP rocks in the western Alps, Bull. Soc. Geol. Fr. $172,617-636$.

Allerton, S., L. Lonergan, J. P. Platt, E. S. Platzman, and E. McClelland (1993), Paleomagnetic rotations in the eastern Betic Cordillera, southern Spain, Earth and Planetary Sciences Lett., 119, 225-241.

Andersen, T. B. (1998), Extensional tectonics in the Caledonides of southern Norway, an overview, Tectonophysics, 285, 333-352.

Andrieux, J., J. M. Fontboté, and M. Mattauer (1971), Sur un modèle explicatif de l'Arc de Gibraltar, Earth Planet. Sci. Lett., 12, 191-198.

Angelier, J. (1984), Tectonic analysis of fault slip data sets, J. Geophys. Res., 89, 5835-5848.

Angelier, J. (1991), Inversion of field data in fault tectonics to obtain the regional stress: A new rapid direct inversion method by analytical means, Geophys. J. Int., 103, 363-376.

Augier, R. (2004), Evolution tardi-orogénique des Cordillères Bétiques (Espagne): Apports d'une étude intégrée, Ph.D. thesis, 400 pp., Univ. de Pierre et Marie Curie, Paris.

Augier, R., G. Booth-Rea, P. Agard, J. M. Martínez Martínez, L. Jolivet, and J. M. Azañón (2005), Exhumation constraints for the lower NevadoFilabride complex (Betic Cordillera, SE Spain): A Raman thermometry and TWEEQU multiequilibrium thermobarometry approach, Bull. Soc. Geol. $F r$, in press.

Avigad, D., C. Chopin, B. Goffé, and A. Michard (1993), Tectonic model for the evolution of the western Alps, Geology, 21, 659-662.

Avigad, D., Z. Garfunkel, L. Jolivet, and J. M. Azañón (1997), Back-arc extension and denudation of mediterranean eclogites, Tectonics, 16, 924-941.

Axen, G., J. Bartley, and J. Selverstone (1995), Structural expression of a rolling hinge in the footwall of the Brenner Line normal fault, eastern Alps, Tectonics, 14, 1380-1392.

Azañón, J. M., A. Crespo-Blanc, and V. García-Dueñas (1997), Continental collision, crustal thinning and nappe forming during the pre-Miocene evolution of the Alpujarride complex (Alboran Domain, Betic), J. Struct. Geol., 19, 1055-1071.

Bakker, H. E., K. De Jong, H. Helmers, and C. Bierman (1989), The geodynamic evolution of the internal zone of the Betic Cordilleras (south-east Spain): A model based on structural analysis and geothermobarometry, J. Metamorph. Geol., 7, 359-381.

Berman, R. G. (1991), Thermobarometry using multiequilibrium calculations: A new technique, with petrological applications, Can. Mineral., 29, $833-$ 855.

Booth-Rea, G., J. M. Azañón, V. García-Dueñas, and R. Augier (2003), Uppermost Tortonian to present depocentre migration related with segmentation of the Palomares Fault Zone (PFZ), SE Betics, Spain, C. R. Acad. Sci, Ser. II, 335, 751-761.

Bouillin, J. P., M. Durand-Delga, and P. Olivier (1986), Betic-Rifian and Tyrhenian Arcs: Distinctive features, genesis, and development stages, in The Origin of Arcs, edited by F. C. Wezel, pp. 281-304, Elsevier, New York.

Braga, M., J. M. Martín, and C. Quesada (2003), Patterns and average rates of late Neogene-Recent uplift of the Betic Cordilleras, SE Spain, Geomorphology, 50, 3-26.

Briend, M. (1981), Evolution morpho-tectonique du bassin Néogène de Huercal-Overa (Cordillères Bétiques orientales, Espagne), Doc. Trav. IGAL 4, 208 pp., Inst. Géol. Albert-de-Lapparent, Paris.

Briend, M., C. Montenat, and P. Ott d'Estevou (1990), Le bassin de Huercal-Overa, in Les Bassins Néogènes du Domaine Bétique Oriental (Espagne), Doc. Trav. IGAL 12-13, edited by C. Montenat, pp. 239-259, Inst. Géol. Albert-de-Lapparent, Paris.

Comas, M. C., V. García-Dueñas, and M. J. Jurado (1992), Neogene tectonic evolution of the Alboran Sea from MCS data, Geo Mar. Lett., 12, 157-164.

Comas, M. C., J. P. Platt, J. I. Soto, and A. B. Watts (1999), The origin and tectonic history of the Alborán basin: Insights from Leg 161 results, Proc. Ocean Drill. Program Sci. Results, 161, $555-579$.
Crespo-Blanc, A. (1995), Interference pattern of extensional fault systems: A case study of the Miocene rifting of the Alboran basement (north of Sierra Nevada, Betic chain), J. Struct. Geol., 17, 1559-1569. Crespo-Blanc, A., V. García-Dueñas, and M. Orozco (1994a), Systèmes en extension dans la Chaîne Bétique Centrale: Que reste-t-il de la structure en nappes du complexe Alpujarride, C. R. Acad. Sci., Ser. II, 317, 971-977.

Crespo-Blanc, A., M. Orozco, and V. García-Dueñas (1994b), Extension versus compression during the Miocene tectonic evolution of the Betic chain: Late folding of normal fault systems, Tectonics, 13, $78-$ 88.

Daniel, J. M., and L. Jolivet (1995), Interaction of detachments and granitic plutons during extension in the Tyrrherian Sea (Elba Island), Bull. Soc. Geol. Fr. 166, 341-354.

De Jong, K. (1991), Tectono-metamorphic studies and radiometric dating in the Betic Cordilleras (SE Spain), Ph.D. thesis, 192 pp., Vrije Univ., Amsterdam, Netherlands.

De Jong, K. (1993), The tectono-metamorphic and chronological development of the Betic zone (SE Spain) with implications for the geodynamic evolution of the western Mediterranean area, Proc. Kon. Ned. Akad. Wet. Nat. Sci., 96, 295-333.

De Jong, K. (2003), Very fast exhumation of highpressure metamorphic rocks with excess ${ }^{40} \mathrm{Ar}$ and inherited ${ }^{87} \mathrm{Sr}$, Betic Cordilleras, southern Spain, Lithos, 70, 91-110.

De Jong, K., and H. Bakker (1991), The Mulhacen and Alpujarride complex in the eastern Sierra de los Filabres, SE Spain: Lithostratigraphy, Geol. Mijnbouw, 70, 93-103.

De Jong, K., G. Féraud, G. Ruffet, M. Amouric, and J. R. Wijbrans (2001), Excess argon incorporation in phengite of the Mulhacén complex: Submicroscopic illitization and fluid ingress during late Miocene extension in the Betic zone, southeastern Spain, Chem. Geol., 178, 159-195.

De Mets, C., R. G. Gordon, D. F. Argus, and S. Stein (1990), Current plate motions, Geophys. J. Int., $101,425-478$. 
Dewey, F. (1988), Extensional collapse of orogens, Tectonics, 7, 1123-1139.

Dewey, J. F., M. L. Helman, E. Turco, D. H. W. Hutton, and S. D. Knott (1989), Kinematics of the western Mediterranean., in Alpine Tectonics, vol, edited by M. P. Coward, D. Dietrich, and R. G. Park, Geol. Soc. Spec. Publ., 45, 265-283.

Egeler, C. G., and O. J. Simon (1969), Orogenic evolution of the Betic zone (Betic Cordilleras, Spain), with emphasis on the nappe structures, Geol. Mijnbouw, 48, 296-305.

England, P., and S. W. Richardson (1977), The influence of erosion upon the mineral facies of rocks from different metamorphic environments, J. Geol. Soc. London, 134, 201-213.

England, P., and A. P. Thompson (1984), Pressuretemperature-time paths of regional metamorphism: I. Heat transfer during the evolution of regions of thickened continental crust, J. Petrol., 25, 849928

Faccenna, C., L. Jolivet, C. Piromallo, and A. Morelli (2003), Subduction and the depth of convection in the Mediterranean mantle, J. Geophys. Res. 108(B2), 2099, doi:10.1029/2001JB001690.

Frizon de Lamotte, D., J. Andrieux, and J. C. Guézou (1991), Cinématique des chevauchements néogènes dans l'arc Bético-Rifain: Discussion sur les modèles géodynamiques, Bull. Soc. Geol. Fr, 4, 33-47.

Frizon de Lamotte, D., J. C. Guēzou, and O. Averbuch (1995), Distinguishing lateral folds in a thrust system: Examples from Corbières (SW France) and Betic cordilleras (SE Spain), J. Struct. Geol., 17, $233-244$

Galindo-Zaldívar, J., F. González-Lodeiro, and A. Jabaloy (1989), Progressive extensional shear structures in a detachment contact in the western Sierra Nevada (Betic Cordilleras, Spain), Geodin. Acta, 3, 73-85.

Galindo-Zaldívar, J. F. González-Lodeiro, and A. Jabaloy (1991), Geometry and kinematic of post-Aquitanian brittle deformation in the Alpujárride rocks and their relation with the Alpujárride/ Nevado-Filábride contact, Geogaceta, 9, 30-33.

Garcia-Castellanos, D., M. Fernàndez, and M. Torne (2002), Modeling the evolution of the Guadalquivir foreland basin (southern Spain), Tectonics, 21(3), 1018, doi:10.1029/2001TC001339.

García-Dueñas, V., J. M. Martínez-Martínez, M. Orozco, and J. Soto (1988a), Plis-nappes, cisaillements synà post-métamorphiques et cisaillements ductilesfragiles en distension dans les Nevado-Filabrides (Cordillères bétiques, Espagne), C. R. Acad. Sci., Ser. II, 307, 1389-1395.

García-Dueñas, V., J. M. Martínez-Martínez, and J. I. Soto (1988b), Los Nevado-Filábrides, una pila de pliegues mantos separados por zonas de cizalla, paper presented at Simposios II Congreso Geológico de España, Soc. Geol. de España, Granada.

García-Dueñas, V., J. C. Balanyá, and J. M. MartínezMartínez (1992), Miocene extensional detachments in the outcropping basement of the northern Alboran basin (Betics) and their tectonic implications, Geo Mar. Lett., 12, 88-95.

Gautier, P., and J. P. Brun (1994a), Crustal-scale geometry and kinematics of late-orogenic extension in the central Aegean (Cyclades and Evia island), $\mathrm{Tec}$ tonophysics, 238, 399-424.

Gautier, P., and J. P. Brun (1994b), Ductile crust exhumation and extensional detachments in the centra Aegaen (Cyclades and Evia Islands), Geodin. Acta, 7, $57-85$.

Gautier, P., J. P. Brun, R. Moriceau, D. Sokoutis, J. Martinod, and L. Jolivet (1999), Timing, kinematics and cause of Aegean extension: A scenario based on a comparison with simple analogue experiments., Tectonophysics, 315, 31-72.

Gómez-Pugnaire, M. T., and J. M. Fernández-Soler (1987), High-Pressure metamorphism in metabasite from the Betic Cordilleras (SE Spain) and its evolution during the Alpine orogeny, Contrib. Mineral. Petrol., 95, 231-244.
González-Casado, J. M., C. Casquet, J. M. MartínezMartínez, and V. García-Dueñas (1995), Retrograde evolution of quartz segregations from the Dos Picos shear zone in the Nevado-Filábride complex (Betic chains, Spain). Evidence from fluid inclusions an quartz c-axis fabrics, Geol. Rundsch., 84, 175-186.

Gunnell, Y. (2000), Apatite fission tracks thermochronology: An overview of its potential and limitations in geomorphology, Basin Res., 12, 115-132.

Gutscher, M. A., J. Malod, J. P. Rehault, I. Contrucci, F. Klingelhoefer, L. Mendes-Victor, and W. Spakman (2002), Evidence for active subduction beneath Gibraltar, Geology, 30, 1071-1074.

Hames, W. E., and S. A. Bowring (1994), An empirical evaluation of the Argon diffusion geometry in muscovite, Earth Planet. Sci. Lett., 124, 161-167.

Hartz, E., A. Andresen, and T. B. Andersen (1994), Structural observations adjacent to a large-scale extensional detachment zone in the hinterland of the Norwegian Caledonides, Tectonophysics, 231, $123-137$.

Henry, C., A. Michard, and C. Chopin (1993), Geometry and structural evolution of ultra-high pressure and high pressure rocks from the Dora Maira massif, western Alps, J. Struct. Geol., 15, 965-981.

Hurford, A. J. (1990), Standardization of fission track dating calibration: Recommendation by fission track working group of the IUGS Subcommission on Geochronology, Chem. Geol., 80, 171-178.

Instituto Geológico y Minero de España (IGME) (1973a), Mapa geologico de España E: 1:50000, Hoja 1013 Macael, Minist. de Ind. y Energia Madrid.

Instituto Geológico y Minero de España (IGME) (1973b), Mapa geologico de España E: 1:50000, Hoja 1030 Tabernas, Minist. de Ind. y Energia, Madrid.

Instituto Geológico y Minero de España (IGME) (1977), Mapa geologico de España E: 1:50000, Hoja 1029 Gergal, Minist. de Ind. y Energia, Madrid.

Instituto Geológico y Minero de España (IGME) (1978), Mapa geologico de España E: 1:50000, Hoja 995 Cantoria, Minist. de Ind. y Energia, Madrid.

Jabaloy, A., J. Galindo-Zaldívar, and F. González Lodeiro (1992), The Mecina extensional system: Its relation with the post-Aquitanian piggy-back basins and the paleostresses (Betic Cordilleras, Spain), Geo Mar. Lett., 12, 96-103.

Jabaloy, A., J. Galindo-Zaldívar, and F. GonzálezLodeiro (1993), The Alpujárride-Nevado-Filábride extensional shear zone, Betic Cordillera, SE Spain, J. Struct. Geol., 15, 555-569.

Johnson, C., N. Harbury, and A. J. Hurford (1997), The role of extension in the Miocene denudation of th Nevado-Filábride complex, Betic Cordillera (SE Spain), Tectonics, 16, 189-204

Jolivet, L., and C. Faccenna (2000), Mediterranean extension and the Africa-Eurasia collision, Tectonics 19, 1095-1109.

Jolivet, L., and M. Patriat (1999), Ductile extension and the formation of the Aegean Sea, in The Mediterra nean Basins: Tertiary Extensions Within the Alpine Orogen, edited by B. Durand et al., Geol. Soc. Spec. Publ., 156, 427-476.

Jolivet, L., J. Daniel, C. Truffert, and B. Goffé (1994) Exhumation of deep crustal metamorphic rocks and crustal extension in arc and back-arc regions, Lithos, 33, 3-30.

Jolivet, L., C. Faccenna, B. Goffé, M. Mattei, F. Rossetti, C. Brunet, F. Storti, J. P. Cadet, and T. Parra (1998a), Mid-crustal shear zones in post-orogenic extensional: The northern Tyrrhenian Sea case, J. Geophys. Res., 103, 12,123-12,160.

Jolivet, L., B. Goffé, R. Bousquet, R. Oberhansli, and A. Michard (1998b), Detachments in high pressure mountains belts, Tethyan examples, Earth Planet Sci. Lett., 160, 31-47.

Jolivet, L., C. Faccenna, B. Goffé, E. Burrov, and P. Agard (2003), Subduction tectonics and exhumation of high-pressure metamorphic rocks in the
Mediterranean orogens, Am. J. Sci., 303, 353409

Kampshuur, W., C. W. Langenberg, J. Baena, F. Velando, G. García Monzón, J. Paquet, and H. E. Rondee (1972), Mapa geológico y minero de España 932 (Coy), Inst. Geol. y Minero de España, Madrid.

Kirschner, D. L., M. A. Cosca, H. Masson, and J. C. Hunziker (1996), Staircase ${ }^{40} \mathrm{Ar} /{ }^{39} \mathrm{Ar}$ spectra of fine-grained white mica: Timing and duration of deformation and empirical constraints on argon diffusion, Geology, 24, 747-750.

Kleverlaan, K. (1989), Neogene history of the Tabernas basin (SE Spain) and its Tortonian submarine fan development, Geol. Mijnbouw, 68, 421-432.

Lammener, B., and M. Weger (1998), Footwall uplift in an orogenic wedge: The Tauern window in the eastern Alps of Europe, Tectonophysics, 285, $213-230$.

Langenberg, C. W. (1972), Gravitational gliding in the northern Sierra de los Filabres (SE Spain), Geol. Mijnbouw, 52, 187-192.

Leblanc, D., and P. Olivier (1984), Role of strike-slip faults in the Betic-Rifian orogeny, Tectonophysics, $101,345-355$

Leine, L. (1966), On the tectonics of the Menas de Seron region, western Sierra de los Filabres, SE Spain, Proc. Kon. Ned. Akad. Wet. Nat. Sci., 69, $403-414$.

Le Pichon, X., N. Chamot-Rooke, and S. Lallemant (1995), Geodetic determination of the kinematics of central Greece with respect to Europe: Implications for eastern Mediterranean tectonics, J. Geophys. Res., 100, 12,675-12,690.

Lister, G. S., and A. Raouzaios (1996), The significance of a porphyroblastic blueschist facies overprint during Alpine orogenesis: Sifnos, Aegean Sea, Greece, J. Struct. Geol., 18, 1417-1436.

Lister, G. S., G. Banga, and A. Feenstra (1984), Metamorphic core complexes of Cordilleran type in the Cyclades, Aegean Sea, Greece, Geology, 12, 221 225.

Lonergan, L., and N. White (1997), Origin of the BeticRif mountain belt, Tectonics, 16, 504-522.

López Sánchez-Vizcaino, V., D. Rubatto, M. T. GómezPugnaire, V. Trommsdorff, and O. Müntene (2001), Middle Miocene high-pressure metamorphism and fast exhumation of the Nevado-Filábride complex, SE Spain, Terra Nova, 13, 327-332.

Malavieille, J. (1993), Late orogenic extension in mountain belts: Insights from the Basin and Ranges and the Late Paleozoic Variscan Belt, Tectonics, 12, $1115-1130$

Malinverno, A., and W. F. B. Ryan (1986), Extension in the Tyrrhenian Sea and shortening in the Apennines as result of arc migration driven by sinking of the lithosphere, Tectonics, 5, 227-245.

Martínez-Martínez, J. M., and J. M. Azañón (1997), Mode of extensional tectonics in the southeastern Betics (SE Spain): Implications for the tectonic evolution of the peri-Alborán orogenic system, Tectonics, 16, 205-225.

Martínez-Martínez, J. M., J. I. Soto, and J. C. Balanyá (2002), Orthogonal folding of extensional detachments: Structure and origin of the Sierra Nevada elongated dome (Betics, SE Spain), Tectonics, 21(3), 1012, doi:10.1029/2001TC001283.

Martínez Martínez, J. M., J. I. Soto, and J. C. Balanyá (2004), Elongated domes in extended orogens: A mode of mountain uplift in the Betics (southeas Spain), in Gneiss Domes in Orogeny, edited by D. Whitney, C. Teyssier, and C. S. Siddoway, Spec. Pap. Geol. Soc. Am., 380, 243-265.

Mayoral, E., A. Crespo-Blanc, M. G. Díaz, C. Benot, and M. Orozco (1994), Rifting Miocène du domaine d'Alboran: Datations de sédiments discordants sur les unités alpujarrides en extension (Sud de la Sierra Nevada, Chaîne Bétique), C. R. Acad. Sci., Ser. II, 319, 581-588.

Mazzoli, S., and M. Helman (1994), Neogene patterns of relative plate motion for Africa-Europe: Some implications for recent central Mediterranean tectonics, Geol. Rundsch., 83, 464-468. 
Monié, P., J. Galindo-Zaldívar, F. González-Lodeiro, B. Goffé, and A. Jabaloy (1991), ${ }^{40} \mathrm{Ar} /{ }^{39} \mathrm{Ar}$ geochronology of Alpine tectonism in the Betic Cordilleras (southern Spain), J. Geol. Soc. London, $148,288-297$.

Monié, P., R. L. Torres-Roldán, and A. García-Casco (1994), Cooling and exhumation of the western Betic Cordilleras, ${ }^{40} \mathrm{Ar} /{ }^{39} \mathrm{Ar}$ thermochronological constraints on a collapsed terrane, Tectonophysics, 238 , $353-379$.

Montenat, C., and P. Ott d'Estevou (1990), Eastern Betic Neogene basins-A review, in Les Bassins Néogènes du Domaine Bétique Orientale (Espagne), Doc. Trav. IGAL 12-13, edited by C. Montenat, pp. 9-15, Inst. Géol. Albert-deLapparent, Paris.

Mora, M. (1993), Tectonic and sedimentary analysis of the Huercal-Overa region, SE Spain, Betic Cordillera, 300 pp., PhD Thesis, Oxford Univ., Oxford, England.

Orozco, M., J. M. Molina, A. Crespo-Blanc, and F. M. Alonso-Chaves (1999), Paleokarst and rauhwacke development, mountain uplift and subaerial sliding of tectonic sheets (northern Sierra de los Filabres, Betic Cordilleras, Spain), Geol. Mijnbouw, 78, $103-117$.

Ott d'Estevou, P., and C. Montenat (1990), Le Bassin de Sorbas-Tabernas, in Les Bassins Néogènes du Domaine Bétique Orientale (Espagne), Doc. Trav. IGAL 12-13, edited by C. Montenat, pp. 101-128, Inst. Géol. Albert-de-Lapparent, Paris.

Parra, T., O. Vidal, and L. Jolivet (2002), Relation between the intensity of deformation and retrogression in blueschist metapelites of Tinos Island (Greece) evidenced by chlorite-mica local equilibria, Lithos, 63, 41-66.

Pascual Molina, A. M. (1997), La Cuenca Néogena de Tabernas (Cordilleras Béticas), 345 pp., Ph.D. thesis, Granada Univ., Granada, Spain.

Platt, J. P. (1993), Exhumation of high-pressure rocks A review of concepts and processes, Terra Nova, 5, $119-133$.

Platt, J. P., and J. H. Behrmann (1986), Structures and fabrics in a crustal-scale shear zone, Betic Cordilleras, SE Spain, J. Struct. Geol., 5, 519-538.

Platt, J. P., and R. L. M. Vissers (1989), Extensional collapse of thickened continental lithosphere: A working hypothesis for the Alboran Sea and Gibraltar Arc, Geology, 17, 540-543.

Platt, J. P., and M. J. Whitehouse (1999), Early Miocene high-temperature metamorphism and rapid exhumation in the Betic-Cordillera (Spain): Evidence from U-Pb zircon ages, Earth Planet. Sci. Lett., $171,591-605$

Platt, J. P., B. Van der Eeckhout, E. Janzen, G. Konert, O. J. Simon, and R. Weijermars (1983), The structure and tectonic evolution of the Aguilón foldnappe, Sierra Alhamilla, Betic Cordilleras, SE Spain, J. Struct. Geol., 5, 519-535.

Platt, J. P., J. I. Soto, and M. C. Comas (1996), Decompression and high-temperature-low-pressure metamorphism in the exhumed floor of an extensional basin, Alboran-Sea, western Mediterranean, Geology, 24, 447-450.

Platt, J. P., J. I. Soto, M. J. Whitehouse, A. J. Hurford, and S. P. Kelley (1998), Thermal evolution, rate of exhumation, and tectonic significance of metamorphic rocks from the floor of the Alboran extensional basin, western Mediterranean, Tectonics, 17, 671-689.

Platt, J. P., S. Allerton, A. Kirker, C. Mandeville, A. Mayfield, E. S. Platzman, and A. Rimi (2003), The ultimate arc: Differential displacement, oroclinal bending, and vertical axis rotation in the Ex- ternal Betic-Rif arc, Tectonics, 22(3), 1017, doi:10.1029/2001TC001321.

Poisson, A. M., J. L. Morel, J. Andrieux, M. Coulon, R. Wernli, and C. Guernet (1999), The origin and development of Neogene basins in the SE Betic Cordillera (SE Spain): A case study of the Tabernas-Sorbas and Huercal-Overa basins, J. Pet Geol., 22, 97-114.

Reicherter, K., and S. Reiss (2001), The Carboneras Fault Zone (SE Spain) revisited with ground penetrating radar: Quaternary structural styles from high-resolution images, Int. J. Earth Sci., 80(34), $11-20$.

Ring, U., M. T. Brandon, S. D. Willett, and G. S. Lister (1999), Exhumation processes, in Exhumation Processes: Normal Faulting, Ductile Flow and Erosion, edited by U. Ring et al., Geol. Soc. Spec. Publ., 154, 1-27.

Rosenbaum, G., G. S. Lister, and C. Duboz (2002), Reconstruction of the tectonic evolution of the western Mediterranean since the Oligocene, J. Virtua Explorer, 8, 107-126.

Royden, L. H. (1993), The tectonic expression of slab pull at continental convergent boundaries, Tectonics, $12,303-325$.

Ruegg, G. (1964), Geologische onderzoekingen in het bekken van Sorbas, S Spanje, 64 pp., Ph.D. thesis, Amsterdam Geol. Inst., Amsterdam Univ., Amsterdam, Netherlands

Sanz de Galdeano, C. (1990), Geological evolution of the Betic Cordilleras in the western Mediterranean, Miocene to the present, Tectonophysics, 172, 107 119.

Sanz de Galdeano, C., and J. A. Vera (1992), Stratigraphic record and palaeogeographical context of the Neogene basins in the Betic Cordillera, Spain, Basin Res., 4, 21-36.

Seber, D., M. Barazangi, A. Ibenbrhim, and A. Denmat (1996), Geophysical evidence for lithospheric delamination beneath the Alboran Sea and Rif-Betic mountains, Nature, 379, 785-790.

Simon, O. J. (1963), Geological investigations in the Sierra de Almagro, SE Spain, Ph. D. thesis, 164 pp., Amsterdam Univ, Amsterdam, Netherlands.

Soto, J. I. (1991), Estructura y evolución metamórfica del Complejo Nevado-Filábride en la terminación oriental de la Sierra de los Filabres (Cordilleras Béticas), Ph.D. thesis, 205 pp., Granada Univ., Granada, Spain

Soto, J. I., and J. M. Azañón (1994), Zincian staurolite in metabasites and metapelites from the BeticCordillera (SE Spain), Neues Jahrb. Mineral. 168(2), 109-126

Soto, J. I., V. García-Dueñas, and J. M. MartínezMartínez (1990), El valor de la deformación dúctil asimétrica en el ortogneis de Lubrín, Almería (Manto de Bédar-Macael, Complejo Nevado-Filábride, Geogaceta, 7, $92-94$.

Spakman, W., and R. Wortel (2004), A tomographic view on western Mediterranean geodynamics, in The TRANSMED Atlas: The Mediterranean Region From Crust to Mantle, edited by W. Cavazza et al. pp. 31-51, Springer, New York.

Tagami, T., and C. Shimada (1996), Natural long-term annealing of the fission track system around a granitic pluton, J. Geophys. Res., 101, 8245-8255.

Torres-Ruiz, J. (1983), Genesis and evolution of the Marquesado and adjacent ore deposits, Granada, Spain, Econ. Geol., 78, 1657-1673.

Trotet, F., L. Jolivet, and O. Vidal (2001a), Tectonometamorphic evolution of Syros and Sifnos islands (Cyclades, Greece), Tectonophysics, 338, 179-206.

Trotet, F., O. Vidal, and L. Jolivet (2001b), Exhumation of Syros and Sifnos metamorphic rocks (Cyclades,
Greece): New constraints on the P-T paths, Eur. $J$. Mineral., 13, 901-920.

Vidal, O., and T. Parra (2000), Exhumation paths of high pressure metapelites obtained from local equilibria for chlorite-phengite assemblages, Geol. J., $35,139-161$

Villa, I. M. (1998), Isotopic closure, Terra Nova, 10 , $42-47$

Vissers, R. L. M. (1981), A structural study of the central Sierra de los Filabres (Betic Zone, SE Spain) with emphasis on deformational processes and their relation to the alpine metamorphism, GUA Pap. Geol. 15, pp. 1-154, Univ. of Amsterdam, Amsterdam.

Vissers, R. L. M., J. P. Platt, and D. van der Wal (1995), Late orogenic extension of the Betic Cordillera and the Alboran Domain: A lithospheric view, Tectonics, 14, 786-803.

Weijermars, R. (1987), The Palomares brittle-ductile shear zone of southern Spain, J. Struct. Geol., 9 , $139-157$

Weijermars, R. (1991), Geology and tectonics of the Betic Zone, SE Spain, Earth Sci. Rev., 31, 153236

Weijermars, R., T. B. Roep, B. Van den Eeckhout, G. Postma, and K. Kleverlaan (1985), Uplift history of a Betic fold nappe inferred from Neogene-Quaternary sedimentation and tectonics (in the Sierra Alhamilla and Almería, Sorbas and Tabernas basins of the Betic Cordilleras, SE Spain), Geol. Mijnbouw, 64, 397-411.

Wernicke, B. (1981), Low-angle normal faults in the Basin and Range Province: Nappe tectonics in an extending orogen, Nature, 291, 645-648.

Wernicke, B. (1992), Cenozoic extensional tectonics of the U.S. Cordillera, in The Geology of North America, vol. G3, The Cordilleran Orogen: Conterminous U.S., edited by B. C. Burchfiel, P. W. Lipman, and M. L. Zoback, pp. 553-581, Geol. Soc. of Am., Boulder, Colo.

Westra, L. (1970), The role of Fe-Ti in plurifacial metamorphism of alpine in the south-eastern Sierra de los Filabres, SE Spain, Ph.D. thesis, 82 pp., Univ. of Amsterdam, Amsterdam, Netherlands.

Zeck, H. P., F. Albat, B. T. Hansen, R. L. TorresRoldán, A. García-Casco, and A. Martín-Algarra (1989), A $21 \pm 2 \mathrm{Ma}$ age for the termination of the ductile Alpine deformation in the internal zone of the Betic Cordilleras, south Spain, Tectonophysics, $169,215-220$

Zeck, H. P., P. Monié, I. M. Villa, and B. T. Hansen (1992), Very high rates of cooling and uplift in the Alpine belt of the Betic Cordilleras, southern Spain, Geology, 20, 79-82.

Zeck, H. P., A. B. Kristensen, and I. S. Williams (1998), Postcollisional Volcanism in a sinking slab setting: Crustal anatectic origin of Pyroxene-Andesite magma, caldear volcanic group, Neogene Alboran volcanic province, SE Spain, Lithos, 45, 499-522.

Zeck, H. P., T. W. Argles, and J. P. Platt (2000), Discussion on attenuation and excision of a crustal section during extensional exhumation, Carratraca peridotite, Betic Cordilleras, southern Spain, J. Geol. Soc., 157, 253-255.

R. Augier and L. Jolivet, Laboratoire de Tectonique, UMR 7072, case 129, Université de Pierre et Marie Curie, 4, place Jussieu, F-75252, Paris Cedex 5, France. (romain.augier@1gs.jussieu.fr)

C. Robin, Geosciences, UMR 4661, Universite de Rennes I, 263 Ave du Général Leclerc, CS 74205, F-35042 Rennes Cedex, France. 